\title{
ARTICLES
}

\section{TAKING "TRADE AND CULTURE" SERIOUSLY: GEOGRAPHICAL INDICATIONS AND CULTURAL PROTECTION IN WTO LAW}

\section{TOMER BROUDE *}

"Each bottle of American and Australian wine that lands in Europe is a bomb targeted at the heart of our rich European culture."

- A winemaker from the Languedoc, circa $2000^{1}$

TABLE OF CONTENTS

1. ANTIPASTI: THE (WORLD) WAR OF THE TWO BEANS ..............625

2. PRIMI: TRADE LAW, CUltURE, FOOD, AND WINE ...................634

2.1. On Culture and Globalization ......................................634

2.2. Trade and Cultural Dimensions:

Production, Consumption, Identity

2.3. Food and Wine as Culture

3. SECONDI: THE ROMANCE OF REPUTATION - THE CASE FOR

CULTURAL PROTECTION THROUGH GEOGRAPHICAL

INDICATIONS.

* Lecturer, Faculty of Law and Department of International Relations, Hebrew University of Jerusalem; BA, LLB, Hebrew University of Jerusalem; SJD, University of Toronto. The Article was presented at an international conference on "The World Trade Organization at a Crossroads," Bar Ilan University, Ramat Gan, Israel, December 12-14, 2004, and at the University of Toronto Law Faculty's Law and Economics Workshop, October 5, 2005. The author is grateful to the participants and others, and in particular Bruce Chapman, Gail Evans, Andrew Green, Aeyal Gross, Larry Helfer, Ed Iacobucci, Ariel Katz, Joel Trachtman, Michael Trebilcock, and Thomas Wälde, for their helpful comments.

1 Quoted in William ECHIKSON, NOBLE Rot: A BORDEAUX WINE REVOlUTION 15 (2004). 
3.1. An Informal Positive Theory of the Law and Economics of Cultural Protection through GIs.......645

3.2. The Culture of Production: Terroir, Traditional Methods of Production, and Rural Culture

3.3. The Culture of Consumption:

Traditions of Discrimination in Taste and Time.

3.4. The Culture of Identity:

Local Champions and Cultural Landscapes

4. CONTORNI: MARKETS AND TRADITION - SOME CONTRARY

ECONOMIC AND CULTURAL REALITIES OF THE FOOD AND

WINE TRADE.

4.1. Can GIs Actually Prevent Market-Induced

Changes to Culture?

4.2. The Culture of Production:

Markets Change Cultures of Production Despite GIs,

Even When Methods Are Regulated

4.3. The Culture of Consumption:

Markets Change Cultures of Discriminating

Consumption Despite GIs

4.4. The Culture of Identity:

The Market for GIs Invents Traditions,

Dilutes Culture and Distorts Identity...

5. DOLCI: THE FUTURE OF CULTURAL PROTECTION IN

WTO LAW.

5.1. Implications for the WTO GI Debate and Beyond

5.2. Thinking About Sui Generis Cultural Protection.

5.3. Thinking About a General GATT/GATS

Cultural Exception

5.4. Thinking About a Parallel UNESCO Regime.

6. Digestivo: Of Cultural Protection AND Cultural

PROTECTIONISM 


\section{ANTIPASTI: THE (WORLD) WAR OF THE TWO BEANS}

The regulation of the relationship between international trade law and cultural protection is one of the challenges that the World Trade Organization ("WTO") will face with greater intensity in the second decade of its existence. Within the WTO, aspects of culture and its sensibilities are being raised as important non-trade considerations to be factored into trade law disciplines either in the context of Article XX of the General Agreement on Tariffs and Trade 1994 ("GATT")/Article XIV of the General Agreement on Trade in Services ("GATS") argumentation," or in the promotion of sui generis trade-related intellectual property rights. ${ }^{3}$ Outside of the WTO, the trade-culture nexus appears in developments in the emerging international law of cultural diversity as promoted within the United Nations Educational, Scientific, and Cultural Organization ("UNESCO"). Such developments are little noticed today, but may in the future impact trade law on the basis of

2 Cultural considerations may conceivably be cited as justifications for exceptions from World Trade Organization ("WTO") trade liberalization disciplines under Article XX(a) of the General Agreement on Tariffs and Trade 1994, Apr. 15, 1994, Marrakesh Agreement Establishing the World Trade Organization, Annex 1A, Legal Instruments-Results of the Uruguay Round, 33 I.L.M. 1125 (1994) [hereinafter GATT], or Article XIV(a) of the General Agreement on Trade in Services, Apr. 15, 1994, Marrakesh Agreement Establishing the World Trade Organization, Annex 1B, Legal Instruments-Results of the Uruguay Round, 33 I.L.M. 1125 (1994) [hereinafter GATS], if deemed "necessary to protect public morals." See Appellate Body Report, United States-Measures Affecting the Cross-Border Supply of Gambling and Betting Services, WTO Doc. WT/DS285/AB/R (Apr. 7, 2005) [hereinafter US-Gambling II] (modifying a panel decision and finding that U.S. federal legislation banning internet supply of gambling services is a restriction on trade in services but that it satisfies the Article XIV(a) of the General Agreement on Trade in Services ("GATS") "necessity" and "public morals" tests, although in part confirming that some of the legislation was discriminatory under the chapeau of GATS Article XIV); or under Article XX(f) of the General Agreement on Tariffs and Trade ("GATT") if "imposed for the protection of national treasures of artistic, historical or archeological value." For a discussion of the legal implications of a general "cultural" exception in WTO law, see infra Section 5 .

3 Such as the Geographical Indications ("GIs") discussed in the present Article or within the more general concept of "Traditional Knowledge." See generally Graham Dutfield, Protecting Traditional Knowledge and Folklore: A Review of Progress in Diplomacy and Policy Formulation, (UNCTAD-ICTSD Project on IPRs and Sustainable Dev., Issue Paper No. 1, 2003) (discussing recognition of traditional knowledge and folklore in the intellectual property framework). 
cultural justifications. ${ }^{4}$

This Article approaches the problem as it is reflected in the current debate on Geographical Indications ("GIs") for food and wine products in the WTO. 5 It seeks to take "trade and culture" seriously, looking at law's effects not only on trade but on culture as well, and to examine the extent to which legal restrictions on international trade can in fact prevent the degradation of cultural diversity in a particular regulatory context. This Article's specific argument, in nuce, is that the conservation of local culture and cultural diversity cannot serve as an independent supporting

4 See Universal Declaration on Cultural Diversity, annex 1, United Nations Educational, Scientific, and Cultural Organization ("UNESCO"), UNESCO Doc. 31C/Res.25, (Nov. 2, 2001), available at http://unesdoc.unesco.org/ images/0012/001271/127160m.pdf [hereinafter UNESCO Declaration]; UNESCO, Preliminary Draft of a Convention on the Protection of the Diversity of Cultural Contents and Artistic Expressions, UNESCO Doc. CLT/CPD/2004/CONF-201/2, July, 2004, available at http://portal.unesco.org/culture/en/file_download.php/1076646d dafe81baa79c6213f7a9190eEng-PreliminaryDraftConv-conf201-2.pdf [hereinafter UNESCO First Draft Convention]; UNESCO, Preliminary Draft Convention on the Protection and Promotion of Cultural Diversity, available in Preliminary Report by the Director-General Setting Out the Situation to Be Regulated and the Possible Scope of the Regulating Action Proposed, annex V, UNESCO Doc. 33 C/23 (Aug. 4, 2005), http://portal.unesco.org/culture/en/file_download.php/2962532f35a06baebb19 9d30ce52956233C23_Eng.pdf [hereinafter UNESCO Second Draft Convention]. During the final editing stage of this Article, on October 20, 2005, the UNESCO Second Draft Convention was adopted by the 33rd Session of the UNESCO General Conference, as the Convention on the Protection and Promotion of the Diversity of Cultural Expressions. Press Release, UNESCO Bureau of Public Information, General Conference Adopts Convention on the Protection and Promotion of the Diversity of Cultural Expressions (Oct. 20, 2005), http://portal.unesco.org/culture/en/ev.php-URL_ID=29078\&URL_DO=DO_TO PIC\&URL_SECTION=201.html.

5 See Agreement on Trade-Related Aspects of Intellectual Property Rights, Apr. 15, 1994, Marrakesh Agreement Establishing the World Trade Organization, Annex 1C, Legal Instruments - Results of the Uruguay Round, 33 I.L.M. 1125, art. 22.1 (1994) [hereinafter TRIPS Agreement] (defining GIs as "indications which identify a good as originating in the territory of a member, or a region or locality in that territory, where a given quality, reputation or other characteristic of the good is essentially attributable to its geographical origin"). This is, however, to some extent a restrictive legal definition. The concept of GIs as eligible for legal protection may be considerably broader, encompassing both "indications of source" (simply indicating the place of production), and "appellations of origin" (indicating a place of production that enjoys certain local environmental characteristics), although the meaning of "geographical indications" in the Agreement on Trade Related Aspects of Intellectual Property Rights ("TRIPS") falls between the two previous terms. BERNARD O'CONNOR, THE LAW OF GEOGRAPHICAL INDICATIONS 22-23 (2004). For this Article's purposes, GIs also include traditional non-geographical names, to which similar considerations apply, see infra note 12 . 
rationale for the expansion and strengthening of the international legal protection of GIs. ${ }^{6}$ Historical experience and empirical evidence, especially in the area of the protection of European wine appellations, show that the national and international legal enforcement of GIs and similar measures has been ineffective in the prevention of cultural transformation and evolution. This includes enforcement brought by transnational and cross-cultural influences that have displaced preexisting traditions and to degrees of cultural homogenization. More broadly, these findings will demonstrate that trade-restrictive or otherwise economically distortive measures are not a dependable means of preserving local culture and traditions, thus casting doubts upon the validity of cultural exceptions in international trade and culture law in general.

Despite common prejudice, ${ }^{7}$ building on food history and sociology to perform a cultural inquiry into this specific topic is neither esoteric nor frivolous. This approach directly addresses one of the underlying complexities of an ongoing trade war (that might be termed the "World War of the Two Beans" 8 ), the contest

6 This does not necessarily imply that other rationales for such protection, such as wealth maximization or consumer protection, do not have merit. These arguments are, however, dealt with in an extensive body of literature. See, e.g., O'CONNOR, supra note 5, at 389-404 (exploring proposals for extending GIs and their costs and benefits). This Article aims to query only the validity of the cultural justification. Furthermore, it is argued that the extension of article 23 of TRIPS "additional protection" for GIs, as explained below, is justified in order to remove the current bias against GIs from developing countries.

7 "Young scholars who are interested in food history are routinely advised not to go near the subject until their second book, after tenure." Warren Belasco, Food Matters: Perspectives on an Emerging Field, in FOOD NATIONS: SELLING TASTE IN CONSUMER SOCIETIES 3 (Warren Belasco \& Philip Scranton eds., 2002).

8 The original "War of the Two Beans" ("La Guerre des Deux Haricots") was a satirical editorial published in the French Le Figaro on September 5, 1908. It lampooned the political struggle for the legal protection of agricultural products and their geographical names in France as instigated primarily by producers of fine wines. "According to Le Figaro, hostilities began in the provinces of France, satirically dubbed the Kingdom of Little Peas. Two Beans, each originating from a different region, confronted each other at the market. One Bean argued that he was the superior vegetable, representative of the refined riches of the Kingdom, endowed with 'unique qualities' and heir to a rich historical legacy. His opposing legume, in the outlandish dialogue that followed, blasted these assertions by laying claim to very similar "unique qualities."' Kolleen M. Guy, Wine, Champagne and the Making of French Identity in the Belle Epoque, in FOOD, DRINK AND IDENTITY: COOKING, EATING AND DRINKING IN EuROPE SinCE THE Middle Ages 163, 163 (Peter Scholliers ed., 2001); see also KOLLEEN M. GUY, WHEN CHAMPAGNE BECAME FRENCH: WINE AND THE MAKING OF A NATIONAL IDENTITY 144-47 (2003) (describing War of 
over the degree, nature, and scope of the international legal protection to be granted to place and place-related names associated with foods, beverages, and other products $^{9}$ (e.g., Parma ham, ${ }^{10}$ Darjeeling tea, ${ }^{11}$ Feta cheese, ${ }^{12}$ and Budvar beer). ${ }^{13}$ The

the Two Beans in further detail). The success of French wine and food producers to solicit legal protection at the national level has been replicated in the European Union, and in the World Trade Organization ("WTO") as well. See infra notes 1617.

9 For a particularly illuminating presentation and analysis of the GI debate, see Elizabeth Barham, Translating Terroir: The Global Challenge of French AOC Labeling, 19 J. RURAL STUD. 127 (2003) (focusing, inter alia, on the notion of terroiressentially the unique connection between place and product that indeed lies at the basis of the entire GI concept). Terroir is undoubtedly part of the cultural justification of GIs discussed here (see infra Section 3), but it is not identical to it. Terroir also has significant non-cultural technical aspects (mainly climate and geology) and may act as the basis for the consumer protection rationale of GI rights, without requiring recourse to cultural arguments. Conversely, the cultural aspects of GIs are not contingent on the scientific validity of terroir. See generally JaCQUES FANET, GREAT WINE TERROIRS (Florence Brutton trans., Univ. Cal. Press 2004) (2001) (exploring the geological basis of wine terroirs); JAMES E. WILSON,

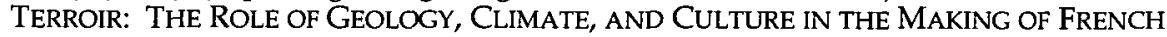
WINES (1998).

10 Indicative of some of the related international legal complications, Parma ham has enjoyed protection as a GI in the European Union, in line with Italian law, since the early 1990s but it has also been a registered trademark in Canada held by Maple Leaf Meats since 1964. O'CONNOR, supra note 5, at 101-02; see also Case C-108/01, Consorzio del Prosciutto di Parma v. Asda Stores Ltd., 2003 E.C.R. I-5163 (addressing the amount of intellectual property protection granted to Parma ham).

11 Darjeeling, the name of a town in the West Bengal state of India famed for the tea it produces, is also a registered trademark in the United States. U.S. Trademark Reg. No. 2,685,923. See Naba Kumar Das, Chairman of the Tea Board India, Presentation to the World Intellectual Property Organization's Worldwide Symposium on GIs: Protection of Darjeeling Tea (July 9-11, 2003), WIPO/GEO/SFO/03/8, available at http://www.wipo.int/meetings/2003/geoind/en/documents/pdf/wipo_geo_sfo_03_8a.pdf (arguing for the strengthening of the Darjeeling tea GI); Niranjan Rao, Geographical Indications in Indian Context: A Case Study of Darjeeling Tea (Indian Council for Research on Int'l Econ. Relations, Working Paper No. 110, 2003) (discussing how the TRIPS Agreement applies to Darjeeling Tea).

12 Feta is an example of a place-related food name that is not strictly speaking a GI since there is, in fact, no relevant geographical place called Feta, which simply means slice or slab in Greek. Under EU law, however, Feta is considered a "traditional non-geographical name" worthy of protection similar to GIs. It is therefore protected as a Protected Designation of Origin ("PDO"). See O'CONNOR, supra note 5, at 130-31 n. 33 (explaining the basis of protection of Feta under EU law). The arguments relating to food, trade and culture presented in this Article essentially apply to PDOs as well as GIs.

13 Budvar is the Czech name for the town of Budweis, the qualitatively unlikely source for the famous commercial U.S. beer brand Budweiser, which is https://scholarship.law.upenn.edu/jil/vol26/iss4/2 
weight of the business interests involved should by itself justify our awareness. The manner in which cultural rationalization has been drawn into this legal-economic field should, however, be of no less concern.

Reflecting its importance in human exchange, food and drink have acquired a special status in international trade law. In the current Doha round of trade negotiations of the WTO,14 it has become clear that the international regulation of the production, consumption, and commercial exchange of food products (at least partially captured by the label "trade in agriculture") ${ }^{15}$ is the ultimate deal-breaker. In disputes adjudicated in the WTO dispute settlement system, food products attract a particularly bright spotlight, ${ }^{16}$ as they have in the European Union ${ }^{17}$ and under the North American Free Trade Agreement ("NAFTA").18 In these contexts, not just food itself, but also food "security" and "safety"

trademarked in the United States and elsewhere. The conflict between the American Budweiser and Budejovickỳ Budvar, the Czech manufacturer of Budweiser Budvar, has reached the WTO's dispute settlement system. Report of the Panel, European Communities-Protection of Trademarks and Geographical Indications for Agricultural Products and Foodstuffs, WT/DS174, ๆ 7.573 (Mar. 15. 2005) [hereinafter EC-GIs].

14 I am referring to the negotiations under the 2001 Doha Declaration. World Trade Organization, Ministerial Declaration of 14 November 2001, WT/MIN(01)/DEC/1, 41 I.L.M. 746 (2002) [hereinafter DDA].

15 Of course, agricultural trade is both broader and narrower than trade in food. On the one hand it encompasses non-food products such as cotton, while on the other hand important food products, most notably fish, have been excluded from the ambit of agricultural trade disciplines. E.8., Agreement on Agriculture, annex 1, I 1, Apr. 15, 1994, Marrakesh Agreement Establishing the World Trade Organization, Annex 1A, Legal Instruments-Results of the Uruguay Round, 1867 U.N.T.S. 410 (1994).

16 By a rough count, approximately $40 \%$ of WTO disputes relate to edible products. For some of the more famous to reach Appellate Body adjudication, see Appellate Body Report, Japan-Taxes on Alcoholic Beverages, WT/DS8/AB/R, WT/DS10/ÄB/R, WT/DS11/AB/4 (Oct. 4, 1996); Appellate Body Report, EC Measures Concerning Meat and Meat Products (Hormones), WT/DS26/AB/R, WT/DS48/AB/R (Jan. 16, 1998); Appellate Body Report, United States - Import Prohibition of Certain Shrimp and Shrimp Products, WT/DS58/AB/R (Oct. 12, 1998).

17 See, e.g., Case 120/78, Rewe-Zentral AG v. Bundesmonopolverwaltung für Branntwein, 1979 E.C.R. 649 (the Cassis de Dijon case, addressing a trade dispute concerning liqueurs and spirits).

18 One such example is the Canada-United States "beer wars" that ensued initially under GATT but were carried over to the North America Free Trade Agreement ("NAFTA") in the anti-dumping context. See NAFTA Binational Panel Report, Certain Malt Beverages from the United States (Injury), CDA-95-1904-1 (Nov. $15,1995)$ (addressing complaints over the importation of malt beverages). 
have become important terms, highlighting the additional sensitivities that accompany edible commodities. ${ }^{19}$

On this background, the issue of geographic indications ("GIs") has emerged on two main fronts in the WTO. First is the front of international negotiation. Paragraph 18 of the Declaration of the WTO 2001 Ministerial Conference (the Doha Development Agenda ("DDA")) places two items relating to GIs on the DDA negotiating table: (i) creating a multilateral system for notification and registration for wines and spirits, under article 23.4 of the Agreement on Trade Related Aspects of Intellectual Property Rights ("TRIPS");20 and (ii) the extension of article 23 of TRIPS "additional protection" of GIs (i.e., protection granted even when there is no risk of misleading consumers or unfair competition) to products other than wines and spirits. The latter point, although formally designated as a DDA paragraph 12 "implementation" issue, essentially entails the potential introduction of new rights and obligations for WTO members. The outcome of these negotiations will determine the scope of statutory protection granted to GIs for years to come.

The second front is that of international litigation. The question of GIs and their protection under TRIPS has inevitably been subjected to WTO dispute settlement.21 A WTO panel recently issued a report with regard to a challenge by Australia and the United States to the existing legislation of the European Union on GIs. The Panel Report found that significant components of the European Union's GI legislation are TRIPS-inconsistent, while other aspects have been upheld by the panel as WTOconsistent.22

19 For a document that places both terms in the context of the right to food as a human right, see Food and Agriculture Organization Council, Report of the 30th Session of the Committee on World Food Security, Supplement, Final Report of the Chair, CL 127/10-Sup.1 (2004), available at http://www.fao.org/docrep/meeting/008/ $\mathrm{J} 3345 \mathrm{e} / \mathrm{j} 3345 \mathrm{e} 01$.htm (arguing for a voluntary set of guidelines to support the progressive realization of the right to adequate food in the context of national food security).

20 See DDA, supra note 14 , at 4 (declaring the intention to establish "a multilateral system of notification and registration of geographical indications for wines and spirits").

21 See, e.g., EC-GIs, supra note 13, at 129.

22 The dispute dealt mainly with two issues: first, whether the European Community's legislation on GI protection discriminates against non-EC GIs (by granting them less than national treatment); and second, whether a registered trademark and EC-recognized GI that are identical can coexist in EC commerce. 
To be sure, in both arenas the debate has focused on technical, legal, and economic considerations that characterize much of the application of GI protection in international and domestic law. There is a distinct cultural backdrop, however, that is often ignored or taken for granted: the assumption that beyond the private interest and public welfare effects of legal protection, GIs are required for the preservation of local traditions, national culture, and cultural diversity. Arguably, this assertion is necessary to justify the inclusion of GIs in intellectual property disciplines that are usually aimed at encouraging the interests of innovation and individual creativity through the grant of a temporary monopoly. ${ }^{23}$ GI rights do not represent these values, as they express commonly used place-names, establish permanent communal rights, and are ostensibly maintained to protect "old knowledge." 24 The notion of GIs as cultural guardians compensates for this justificatory deficiency, providing an alternative quasi-intellectual property theoretical basis.

The main proponent of this cultural rationale is the European Union, which has also broadened the cultural argument to apply to developing countries, claiming that GIs "are key to EU and developing countries cultural heritage, traditional methods of production and natural resources." 25 Indeed, the claim that GIs

See Report of the Panel, European Communities-Protection of Trademarks and Geographical Indications for Agricultural Products and Foodstuffs, WT/DS290/R (Mar. 15,2005 ) (detailing Australia's claim of discrimination by the European Union against non-EU countries regarding the protection of GIs); see also EC-GIs, supra note 13, at 120-24 (stating that article 14(3) of the TRIPS Agreement does not prevent the registration of a GI on the basis that its use would affect any prior trademark outside a subset of trademarks which excludes trademarks with no reputation, renown, or use). Consistent with these rulings, Budweiser can coexist in EC commerce. Id.

23 See, e.g., Karl Shell, Toward a Theory of Inventive Activity and Capital Accumulation, 56 AM. ECON. REV. 62, 64 (1966) (noting that in the United States the legal concept of the patent was attached to various inventive outputs to secure its economic value and impact); Allyn A. Young, Increasing Returns and Economic Progress, 38 ECON. J. 527, 533 (1928) (describing how economic progress comes from changes initiating more change which "becomes progressive and propagates itself in a cumulative way").

24 "Old Knowledge" is sometimes a euphemism for tradition and culture. See Dutfield, supra note 3 , at 23 (discussing the argument that what characterizes something as traditional is not "its antiquity, but the way it is acquired and used").

25 Delegation of the European Commission to Japan, Why Do Geographical Indications Matter to Us?, EU Background Note 01/04, Feb. 10, 2004, http://jpn.cec.eu.int/home/news_en_newsobj553.php [hereinafter EU Back- 
can protect local culture has also been taken up by certain developing countries that are understandably interested in acquiring enhanced international GI protection for products other than wine and spirits. ${ }^{26}$ Given that most GI wines and spirits are produced in developed countries, the current law places developing countries at a disadvantage. Moreover, the proposition that GI protection can help preserve tradition (or can be justified on this basis) is usually taken at face value. ${ }^{27}$ Critically examining this assumption in this Article, I do not wish to argue that local culture and traditions are unworthy of protection, nor that cultural diversity should not be encouraged, but only that history as well as informed economic analysis demonstrate that GIs are a questionable way of doing so. Indeed, this will lead to more general conclusions on the legal protection of culture through trade restrictions with applications that transcend the current study of GIs.

In keeping with its subject matter, this Article will follow the path of five courses and a bit more. After this (hopefully appetizing) introduction, Section 2, titled "Primi: Trade Law, Culture, Food, and Wine" will expand on the more general context of the trade-culture nexus. First, I will briefly describe existing

ground Note].

26 See, e.g., Council for Trade-Related Aspects of Intellectual Property Rights, Minutes of Meeting Held in the Centre William Rappard on 25-27 and 29 November, and 20 December 2002, IP/C/M/38 at 41 (Feb. 5, 2003) (documenting intervention by the delegate from Thailand, who asserted that "[e]xtension was important because GIs were often related to culture and ancestors' traditional knowledge"); Council for Trade-Related Aspects of Intellectual Propert Rights, Minutes of Meeting Held in the Centre William Rappard on 25-27 June 2002, IP/C/M/36/Add.1 at 9-10 (Sept. 10, 2002) (noting that several countries have co-sponsored a proposal by India to extend GI protections to teas, coffees, rice, bananas, carpets, handicraft, and other products). Also, most of the third-parties in the EC-GIs Panel proceedings were developing countries. See EC-GIs, supra note 13, for a review of the number of developing countries acting as third-parties in such proceedings.

27 For example, Echols states,

The preservation of traditions and of community values may be of such significance that it helps to define and to distinguish a neighborhood or a community. Traditions maintain a sense of community and society. Traditions made 'new' could offer a lifeline to a rural community and might offer enough cachet for a few of its young adults who otherwise would flee to the city. Communities could be beneficiaries of the use of GI's.

Marsha A. Echols, Geographical Indications for Foods, TRIPS, and the Doha Development Agenda, 47 J. AFR. L. 199, 201 (2003) (footnote omitted). 
perceptions of the relationship between culture as a "national" or localized ideal, on one hand, and "globalization," as a universalized counter-notion, on the other hand. I will discuss the broad scope of conceivable conflicts between international trade disciplines and national or local cultural assets and policies, as expressed by and expressive of three dimensions of culture: production, consumption, and identity. Thereafter, food and wine will be drawn into the fray not merely as agents of subsistence, ingestion, or intoxication but as reflective of culture, in the specialized local/national and global diversity senses.

In Section 3, titled "Secondi: The Romance of Reputation-The Case for Cultural Protection Through Geographical Indications," I will present an informal, positive (yet romantic) theory of the law and economics of cultural protection through GIs, and expand on the role of cultural justification in existing perceptions of GIs. In this regard, particular attention will be granted to the previously identified cultural dimensions of production, consumption, and identity.

In Section 4, titled "Contorni: Markets and Tradition-Some Contrary Economic and Cultural Realities of the Food and Wine Trade" will examine specific factual aspects of the history of the wine and food trade that contradict the romantic view of GIs as possible protectors of culture. These will ultimately expose the cultural rationalization of GIs, and its underlying legal and economic theory as unpersuasive.

In Section 5, titled "Dolci: The Future of Cultural Protection in WTO Law," I will summarize conclusions from the investigation of the cultural aspects of GIs, and argue that GIs are inadequate cultural protectors, and that the cultural rationale should not influence the outcome of the Doha Round on these issues. More generally, I will draw some lessons for the future role to be played by cultural protection exceptions and argumentation, in three legal areas: sui generis trade restrictions (such as GIs), the employment and possible expansion of Article XX of GATT and Article XIV of GATS as a general "cultural exception" to trade disciplines, and the establishment of a separate international legal regime for cultural diversity, as suggested in the UNESCO Draft Convention, that would impact upon WTO law.

A short Digestivo will follow, offering a few thoughts on the nature of cultural diversity and culture-based protectionism. 


\section{Primi: Trade LAW, Culture, FoOd, AND Wine}

\subsection{On Culture and Globalization}

The popular perception of the effects of globalization on world cultures is the apocalypse of a "McWorld": "[T]he onrush of economic and ecological forces that demand integration and uniformity . . . pressing nations into one commercially homogenous global network..."28 In this vision, fragile local social and cultural structures are erased by exposure to powerful external forces. These are brought to bear by the onslaught of electronic telecommunications (an argument first presented by Herbert Schiller, well before the advent of the internet) ${ }^{29}$ and other enhanced transnational interactions, which promote a global culture of "consumerism." This acculturation couples with free trade to cause local customs, products, and production methods to be vanquished by foreign, globally available alternatives. The global proliferation of standardized products of mass culture thus threatens to stifle national and local modes of cultural expression. ${ }^{30}$

Beyond this stylized depiction, however, we must acknowledge the wealth of nuanced and constantly developing theorizing on globalization and culture. Of course, the basic scenario owes much to Neo-Marxist thought, for it is often asserted that the devastation of local cultures is the product of a triumph of cultural hegemony ${ }^{31}$ or cultural imperialism ${ }^{32}$ on the ideological battleground of culture. ${ }^{33}$ The result of which, in the "third world" context, is westernization or "Americanization." These views,

28 Benjamin R. Barber, Jihad vs. McWorld, ATLANTIC MONTHLY, Mar. 1992, at 53, 53; see also BENJAMIN R. BARBER, JIHAD vs. MCWORLD: HOW GLOBALISM AND TRIBALISM ARE RESHAPING THE WORLD (Ballantine Books 1996).

29 SeE Herbert I. SCHILlER, MASS COMMUNiCATIONS AND AMERICAN EMPIRE 112 (1969) ("Everywhere local culture is facing submersion from the massproduced outpourings of commercial broadcasting").

30 See generally Jürgen Habermas, The POSTnAtional Constellation: Political Essays 72-112 (Max Pensky ed. \& trans., MIT Press 2001) (1998) (analyzing the dichotomies of modern globalization).

31 "Cultural hegemony" may grossly simplify the Gramscian term. See, e.g., ANTONITO GRAMSCI, SElections FROM THE PRISON NOTEBOOKS (Quintin Hoare \& Geoffrey Nowell Smith eds. \& trans., Int'l Publishers 1971).

32 For a full and critical exposition of the term, see generally JOHN TOMLINSON, CULTURAL IMPERIALISM: A CRITICAL READER (1991).

33 Immanuel Wallerstein, Culture as the Ideological Battleground of the Modern World-System, 7 THEORY, CULTURE \& SOCIETY 31, 31 (1990). 
however, are wide open to criticism from all corners. For example, it has been argued that the notion of western cultural domination is itself a self-serving western concept, that "'[c]ultural imperialism' is a critical discourse which operates by representing the cultures whose autonomy it defends in its own (dominant) Western cultural terms." 34 Some theorists reject the danger of the domination by a western monoculture, observing instead the emergence of "global cultures in the plural." 35 Others explain how national cultures have post-modernly "reconceived themselves in order to persist in an era of intensified globalization." 36

Though much of the following analysis may modestly contribute to the discussion, for immediate purposes it is not necessary to enter this debate. Few, if any, would argue that globalization, however conceived, does not produce any changes in local cultures and traditions. Indeed, signaling that there is at least some consensus on the existence of the problem, UNESCO has been exploring the loss of cultural diversity due to economic pressures for a decade. ${ }^{37}$ The academic and at times ideological debate is thus primarily descriptive (inquiring as to the nature and extent of the changes produced) or normative (inquiring if the changes are positive or negative). The fact that the phenomena exist is not usually questioned.

34 TOMLINSON, supra note 32 , at 2.

35 MiKe FeAtHeRstone, CONSUMER Culture AND POSTMOdERnism 10 (1991); see also Ulf Hannerz, Cosmopolitans and Locals in World Culture, in 7 THEORY, CULTURE \& SOCIETY 237, 243-44 (1990) (noting the interaction of territorial cultures with occupationally divided, transnational cultures).

36 Frederick Buell, National Culture and the New Global System 12 (1994). See generally JOHN R. HAll \& MARY Jo NeITZ, CulturE: SOCIOlOGical Perspectives (1993); Culture, Globalization AND tHE World System: CONTEMPORARY CONDITIONS FOR THE REPRESENTATION OF IDENTITY (Anthony D. King ed., 1997); GEORGE RITZER, THE MCDONALDIZATION THESIS (1998); 12 PuB. CULTURE (2000) (providing background material on Globalization (issue 12.1), Millennial Capitalism and the Culture of Neoliberalism (issue 12.2), and Cosmopolitanism (issue 12.3)).

37 See, e.g., UNESCO, OUR CREATIVE DIVERSTTY: REPORT OF THE WORLD COMMISSION ON CULTURE AND DEVELOPMENT, http://kvc.minbuza.nl/uk/archive/report/intro.html (last visited Nov. 15, 2005) (establishing that, in 1993, UNESCO founded the World Commission on Culture and Development to explore the relationship between culture and development). For a more recent discussion of the effect of development on culture, see Round Table of Ministers of Culture: Final Report, in UNESCO, 2000-2010: CULTURAL DIVERSITY: CHALLENGES OF THE MARKETPLACE, (2000) available at http://www.unesco.org/culture/development/highlights/texts/html_eng/Rap portFinal-Eng.rtf. 


\subsection{Trade and Cultural Dimensions: Production, Consumption, Identity}

The "trade and culture" debate characterizes trade-or, rather, trade liberalization as enforced through the reciprocal trade obligations of the GATT/WTO and regional trade agreements - as an agent of the forces of global cultural change. Free trade brings new imported products, services, and production methods to the domestic market; each potentially a cultural influence that alters local tradition. Clearly, those who feel that their culture is at risk because of exposure to such global influences will protest and confront the international law that facilitates it. ${ }^{38}$ In the context of trade, however, it is just as likely that those whose economic, noncultural interests are threatened by international competition will use cultural arguments as a protectionist defense. Thus, as in many other trade-related or "trade and _- issue areas, ${ }^{39}$ strange bed-fellowships may form to resist change. Marxists and capitalists, cottage industries and multinational corporations, artisans and industrialists may all argue that national culture is being compromised by international trade. As in other interactions between trade and non-trade values, the problem is in drawing the line between disguised trade protectionism and bona fide cultural policy, a dilemma that clearly arises when trade disciplines and cultural interests clash.

In the existing legal and regulatory spheres, conflicts between trade liberalization and cultural policy can arise in a broad variety

38 See generally Russell Mokhiber \& Robert Weissman, Top 10 Reasons to Shutter the WTO, MOTHER JONES, Nov. 24, 1999, http://www.motherjones .com/news/feature/1999/11/fotc12.html (citing "prioritization of commercial over other values" as a fundamental flaw of the WTO); Weekend Edition: Saving Slow Food in Turin by Sulvia Poggioli (NPR radio broadcast Nov. 7, 2004) available at http://www.npr.org/templates/story/story.php?storyId $=4157137$ (documenting a "taste fair" in Turin, Italy that "grew out of a protest against the opening of the first McDonalds in Rome"); Irene McConnell, Looking Back at the "Battle Of Seattle": Understanding the WTO, and the Roots of Civil Society's Rage, POST, Summer 2000, available at http://www.ualberta.ca/PARKLAND/post/Vol-IV-No2/05mcconn ell.html (" $[C]$ ommunal identity needs to he nurtured and protected against those who insist that culture is a commodity subject to the laws and values of the market place").

39 For a broad perspective on the issues concerning the "trade and - " problem, see generally Meinhard Hilf \& Goetz J. Goettsche, The Relation of Economic and Non-Economic Principles in International Law, in INTERNATIONAL ECONOMIC GOVERNANCE AND NON-ECONOMIC CONCERNS: NEW CHALlENGES FOR THE INTERNATIONAL LEGAL ORDER 5 (Stefan Griller ed., 2003), and Symposium, The Boundaries of the WTO, 96 AM. J. INT'L L. 1 (2002). 
of trade contexts. Prohibitive tariffs, import bans, quantitative restrictions, discriminatory taxation, subsidies, domestic content requirements, regulatory prohibitions, licensing restrictions, and foreign investment constraints have all been used 40 -and in some cases challenged ${ }^{41}$-inter alia, in the name of cultural protection. The propensity of trade disciplines to interfere with cultural policy is thus obvious. On the non-trade, cultural side of the coin, the question therefore arises: what is actually being protected by cultural policy? For many reasons, the "trade and culture" debate has so far centered on the film and television industries, "to the extent that the term 'culture' became synonymous with the word 'audiovisual.'" 42 Yet the recent U.S.-Gambling case and references to culture in broader contexts show (as should perhaps be selfevident) that culture is much more than television ${ }^{43}$-indeed, cultural aspects may be found in virtually any aspect of human activity. The UNESCO Declaration ${ }^{44}$ goes so far as to state virtually all-inclusively that "culture should be regarded as the set of distinctive spiritual, material, intellectual and emotional features of society or a social group, and that it encompasses, in addition to art and literature, lifestyles, ways of living together, value systems, traditions and beliefs." 45

It therefore seems futile to undertake the task of comprehensively defining or delimiting "culture." Instead, assuming that culture is an inherently broad and subjectively delimited concept, it would perhaps be more effective to identify the dimensions of culture-however defined - that may be affected by trade in any good or service (generally, the culture-related aspects of trade). To this end, let us simply assume that culture, generally conceived as a value, may be attached to all forms of

40 See Mary E. Footer \& Christoph B. Graber, Trade Liberalization and Cultural Policy, 3 J. INT'L. ECON. L. 115, 122-26 (2000) (surveying the usual measures by which WTO member countries pursue national cultural policies to regulate the trade of audiovisual media).

41 See, e.g., Appellate Body Report, Canada-Certain Measures Concerning Periodicals, WTO Doc. WT/DS31/AB/R (1997); US-Gambling II, supra note 2. See infra Section 5.2 (discussing sui generis cultural protection in greater detail).

42 Footer \& Graber, supra note 40, at 119.

43 US - Gambling II, supra note 2.

44 UNESCO Declaration, supra note 4.

45 Id. at pmbl.; see also id. art. 1 (noting the objectives of the convention to be protection and promotion of cultural diversity; encouragement of respect, free evolution, and interaction of culture; and facilitation of the development and adoption of policies to advance such diversity, evolution, and interaction). 
human exploit and existence. In the trade context, imagine a commoditized and valorized human effort, a widget, which has, in this sense, some constituent cultural value (note that a widget service, rather than good, may also qualify). The UNESCO First Draft Convention followed a similar conceptual approach (in article 4) by defining "Cultural Goods and Services" as goods, services and other activities that embody or yield "Cultural Expressions," which are in turn defined as either "Cultural Content" (the symbolic meaning or cultural values communicated or conveyed by the good, service or activity) or "Artistic Expression" (the result of creative work or aesthetic creation). ${ }^{46}$ The relationship between Cultural Content and Artistic Expression in the UNESCO First Draft Convention is not entirely clear, but it appears that the drafters considered all creative and aesthetic work to be an expression of culture, even if it has no "Cultural Content" - i.e., it has no symbolic value or intrinsic cultural value. Moreover, in the UNESCO Second Draft Convention, reference to "Artistic Expressions" has been dropped and merged into the broader term of "Cultural Expressions," and the term "Cultural Goods and Services" has been expanded to include "Cultural Activities," which may contribute to the production of cultural goods and services or be an end in themselves. ${ }^{47}$

Returning to the present analysis (and departing from the sometimes awkward definitions of the UNESCO Draft Conventions), it is suggested that a widget may generally become cultural in three possible (but non-mutually exclusive) ways: through the culture of its production; the culture of its consumption; or the culture of its identity. More specifically:

The culture of production: 48 In this sense, it is the process of the

46 UNESCO First Draft Convention, supra note 4, art. 4.

47 UNESCO Second Draft Convention, supra note 4, art. 4.

48 This cultural attribute superficially corresponds to the requirement in article 4(4)(a) of the UNESCO First Draft Convention that "Cultural Goods or Services" be the "outcome of human labour (industrial, artistic or artisanal) and require the exercise of human creativity for their production." UNESCO First Draft Convention, supra note 4, art. 4(4)(a). On one hand, however, the inclusion of the "industrial" category of labor expands the definition to include massproduced goods and services that might otherwise have been considered of no particular value in the sense of a "culture of production" as employed here. On the other hand, the current wording of this article appears to establish this requirement as one of a series of cumulative conditions for the existence of a "Cultural Good or Service," so that mass-produced goods might not be considered "cultural" if they did not "express or convey some form of symbolic 
widget's creation and/or the method of its production that ordain it with cultural value that is to be protected. A painting, a literary manuscript or a musical score would quite clearly fall into this category; but such widgets may also be cultural in the manner of their consumption, not just their production. More restrictively, a widget's culture-ness may be related to production without even being apparent in the use of the finished product. For example, a handmade kilim that will lie on the floor and be trod upon by muddy boots can hardly be said to have cultural value unless one acknowledges the artisanal craft involved in its production; 49 the same function can be fulfilled by mass-produced, synthetic rugs. In this category, the assault of globalization threatens not the commodity produced but its underlying productive culture. The loss of the product due to cultural homogenization and massculture is not, perhaps, the true cultural cost. Like the pottery of Cipriano Algor in Saramago's The Cave, 50 it is the method of production and the lifestyle that both supports it and is supported by it, that may be displaced by alternative products, industrial substitutes, and indifferently shifting consumer tastes. The consumer may be oblivious to the "make" of the product: a handmade ceramic vase and machine-made one will do just as well; but the knowledge and culture of handicrafts will be irreparably lost in the process.

The culture of consumption:51 In this category, the widget

meaning," id. art. 4(4)(b), and "generate... intellectual property, whether or not they are protected under existing intellectual property legislation," $i d$. art. 4(4)(c). This final requirement also raises several problems in the context of GIs (although not directly relevant to the current Article's subject matter and analysis). If cultural protection is granted only to goods that constitute "intellectual property," this may imply an expansion of the latter term beyond its classical definitional confines and rationales. But if for this purpose such intellectual property need not be protected by intellectual property law, how is it to be definitely recognized as intellectual property? Moreover, these issues appear to have been bypassed (if not solved) in the UNESCO Second Draft Convention, which refers to "creativity," but not to "industrial labour" or "intellectual property."

49 See, e.g., Peter Davies, The Tribal Eye: Antique Kilims Of Anatolia (1993) (discussing the tradition of Kilim weaving). (2000).

50 José Saramago, The Cave (Margaret Jull Costa trans., Harcourt 2002)

51 This is a cultural aspect that appears to have been neglected by the drafters of the UNESCO Draft Convention in defining Cultural Goods and Products, although it may be discerned in several peripheral aspects of the Second Draft Convention, supra note 4 , art. 4 , and in particular in the broad concept of "Cultural Activities." 
becomes cultural by virtue of the context in which it is consumed, the way it is used. The cultural value of the production of the widget, taken on its own, is not necessarily at risk. For example, the demand for music once spawned a tradition of musical performances, expressed through the sometimes elitist culture of concert and opera attendance, but also that of the dance-hall and the folk musician. When the same performances became available, with enhanced audio quality, through mass-produced longplaying records, the social context of consumption changed, from the communal to the private. Things are more complicated; audiovisual technologies now enable a single artist to publicly perform, live, in front of tens of thousands instead of selected dozens, but here too the context of cultural consumption has changed. Much the same could be said about the shift from cinema to homeviewing via VCRs or pay-per-view video. In academia, a shift in the culture of consumption is evident as more and more primary sources, journals, and books become available online in searchable electronic format. It is no longer necessary to physically browse the bookshelves, leaf through dusty books, and even read through copious amounts of interesting (or not) but irrelevant material. Electronic databases, Google, and other search functions do the hard work. The context of consumption has thus clearly changed, even for literary works whose production cannot have changed, if only because they were produced centuries ago. ${ }^{52}$

The culture of identity:53 This is perhaps the least tangible manner in which local culture may attach to a widget. In this case, there is nothing idiosyncratic in the widget's production or in its consumption, but culture is nevertheless embedded in the widget by its very existence, and through its content, such that it is

52 For example, the complete works of William Shakespeare are available online in easily accessible electronic and searchable form through several websites. See, e.g., William Shakespeare-Biography and Works, http://www. online-literature.com/shakespeare (last visited Dec. 2, 2005) (offering biographical information about William Shakespeare and searchable versions of all of his texts, as well as delivery of a sonnet per day via e-mail); William Shakespeare at eNotes, http://www.shakespeare.com (last visited Dec. 2, 2005) (making available the text of William Shakespeare's works as well as poetry-related games and activities).

53 The "culture of identity" that may be attributed to a good or service was expressly acknowledged in the UNESCO First Draft Convention, supra note 4, at article 1(a) (identifying cultural goods as vehicles of "identity, values and meaning"), in article $4(4)$ (b) (using symbolic meaning as component of definition of "Cultural Goods and Services"), and in similar language in the Second Draft Convention, supra note 4 , in articles $1(\mathrm{a})$ and $4(4)(\mathrm{b})$. 
somehow representative of a cultural value that is associated with the relevant group's identity. A national flag is a concrete example, though not a very helpful one in the trade perspective. Every nation has a flag, and they are all produced and "consumed" in essentially the same way, yet the graphic content of each one is steeped in a special historiography and imagery that both express and facilitate the creation of national identity. ${ }^{54}$

In the context of identity, a widget becomes cultural by association with a cultural group and through symbolism. In the area of international trade, the dominant issues of audio-visual and other media services demonstrate the centrality of "identity" as a parameter of culture well. The production and consumption of magazines and television programming in Canada and the United States is in essence the same, and, yet, Canada has cited national culture in defense of its policies in these fields. ${ }^{55}$ This is not only because Canadian media content is different from U.S. content; rather the content is particularly Canadian - the preservation of which is important for the continuation of Canadian culture. If the Canadian-ness of Canadian magazines were erased by commercial integration, an important part of Canadian identity would ostensibly be obliterated. Clearly, the culture of identity has a strong subjective element, but it cannot be ignored in the tradeculture debate; in fact, it might lie at its core.

To more or less complete this picture, the cultural charge of a widget as assumed on any of these three levels can be either positive or negative. If the traditional method of production is "positively" cultural in representing a local culture of production, the modern, international or dominant foreign method that threatens it becomes a "negatively" cultural widget and its nemesis. For example, if it is argued that local culture is

54 See, e.g., KIt Hinrichs \& Delphine Hirasuna, long May She Wave: A GRAPHIC HISTORY OF THE AMERICAN FLAG (2001) (tracing the evolution of the U.S. flag and the extent to which it has become ingrained in popular U.S. culture); JoHN Ross Matheson, CANAdA's FlaG: A SEARCH For A COUNTRY (1980) (paralleling the development of the Canadian national flag with the quest for a Canadian national identity).

55 See, KeIth ACHESON ANd Christopher Maule, Much Ado AbOut Culture: NORTH AMERICAN TRADE DISPUTES (1999) ("National culture is nurtured as a byproduct of consuming cultural products."); Chi Carmody, When 'Cultural Identity Was Not an Issue': Thinking About Canada-Certain Measures Concerning Periodicals, 30 LAW \& POL'Y INT'L. REL. 231 (1999) ("Often there is tension between freer trade and cultural autonomy, principally because of how we think and what we think about."). 
characterized by public morals that abhor gambling or pornography, the cross-border internet services that supply them become "negatively" cultural widgets.

These three dimensions of culture-production, consumption and identity - should help us better understand the cultural basis of the arguments for increased GI protection for food and wine products. However there is first an important aside: are food and wine even remotely "culture"?

\subsection{Food and Wine as Culture}

There is no question that "food is important," 56 as the source of nutrition and sustenance, on a world-wide scale. Halving the global proportion of malnutrition and hunger - those who simply do not have access to enough food-regardless of its quality or provenance, has become an internationally agreed upon policy goal.57 But even if, and when, this target is achieved, the world's hungry will still amount to many hundred millions, 58 by all means a mind-boggling number. Yes, certainly in these terms, food is important.

The centrality of food in our human lives far transcends the primary physical context of nourishment, and easily takes on additional cultural or quasi-cultural dimensions. Food is a lucrative, tradable commodity, a foundation of personal and corporate income, a visibly significant component of the economy, and, not least of all, a source of human delight. "There is in fact nothing more basic. Food is the first of the essentials of life, our biggest industry, our greatest export, and our most frequently indulged pleasure."59 Food is also an important expression of cultural practices, perceptions, and identities, both individual and collective. Brillat-Savarin's celebrated quip on the subject has rightly become a truism. ${ }^{60}$ Indeed, following somewhat more

56 Belasco, supra note 7 , at 2.

57 G.A. Res. 55/2, ๆ 19, U.N. Doc. A/RES/55/2 (Sept. 8, 2000).

58 See UN, Department of Economic and Social Affairs, Nutrition, Undernourished as a Percentage of Total Population, available at http://millenniumindicators.un.org/unsd / $\mathrm{mi} / \mathrm{mi}$ _series_results.asp?rowId $=566$ (last visited Dec. 2, 2005) (documenting the global toll of hunger).

59 Belasco, supra note 7, at 2.

60 See 1 Anselme Brillat-Savarin, Physiologie Du Gout [Physiology of TASTE] 3 (Paris, Bibliotheque Nationale 1877) (1825) ("Dis-moi ce que tu manges, je te dirai ce que tu es." ["Tell me what you eat, I will tell you what you are."]). One 
rigorous research, anthropologists have similarly concluded that "food is also a symbolic marker of membership (or nonmembership) in practically any sort of social grouping."61 Although not necessary for subsistence, alcoholic drinks are undoubtedly as intertwined with our social imagery as food. 62

In the clearest historical terms, the most significant shifts in early human development have related to innovative patterns of food production and consumption, most noticeably the move from hunting-gathering to agricultural practices, 63 a harbinger of urbanization, technological progress, and ultimately, industrial production. History can also be convincingly retold through the prism of specific important foodstuffs, such as the potato ${ }^{64}$ or chocolate. ${ }^{65}$ Throughout considerable chronological space, each human civilization has been characterized not only by its plastic art, literature, and politics, but also - and at least as relevantly, without belaboring the point-by its cuisine and food habits. Food, in this regard, has been likened to language, as an expression of national and local culture. ${ }^{66}$

wonders what this says of the individual dignity of each of the aforementioned world's famished.

61 Sidney W. Mintz, Food and Eating: Some Persisting Questions, in FOOD NATIONS: SElling TASTE IN CONSUMER SOCIETIES, supra note 7, at 26.

62 See, e.g., GiovanNi Rebora, Culture Of THE Fork: A Brief History OF FOOD IN EUROPE 153 (Albert Sonnenfeld trans., 2001) (1998) ("The vine and wine, wrote Fernand Braudel, are products of civilization...."); A. Lynn Martin, Old People, Alcohol and Identity in Europe, 1300-1700, in FOOD, DRINK AND IDENTITY: COOKING, EATING AND DRINKING IN EUROPE SINCE THE MIDDLE AGES, supra note 8, at 119, 119-37 (discussing how alcohol in the 1300s-1700s was part of the identity of older people in Europe).

63 See generally JAREd DiAmOND, Guns, Germs AND STEEL: THE FATE OF HUMAN SOCIETIES (1999) (describing the critical role of agricultural endowments on social and economic progress). For a kaleidoscopic work on the interaction between food, history, and society, see REAY TANNAHILL, FOOD IN HISTORY (1973) (showing that the way in which the pursuit of more and better food has helped to direct the movement of history itself).

64 See generally LARRY ZuCKeRMAN, THE POTATO: HOW THE Humble SPUD RESCUED THE WESTERN WORLD (1998) (revealing how western domestic and social life functioned by describing how potato achieved its influence on our life today); REDCLIFFE N. SALAMAN, THE HISTORY AND SOCIAL INFLUENCE OF THE POTATO (3rd ed. 1985) (explaining the taxonomy of the potato and its wild relatives, its archaeological background, the history of its discovery and introduction into Europe, and its social and economic history).

65 See Sophie D. Coe \& Michael D. Coe, The True History Of Chocolate (1996) (describing that, in its history, chocolate had "immense importance socially, religiously, medically, economically, and of course gastronomically").

66 See Mintz, supra note 61, at 26 ("Imagine convincing the Russian people to 
Thus, food is as an essential element of our culture as any, however defined, albeit perhaps taken for granted by many. ${ }^{67}$ It is important at all levels of human individuality and social interaction. Scholars David Bell and Gill Valentine make this point necessarily and comprehensively - in contexts virtually extraneous to the present one-relating the role of food in the political perception of our body, home, community, city, region, nation, and global environment. ${ }^{68}$ Indeed, at all levels of analysis, food and drink most easily lend themselves to the production-consumptionidentity triad of culture presented above, as the joint crop of the earth and human inventiveness, as goods whose only use is in their physical consumption, and as representatives of significantly broader contexts of identity.

It is therefore evident that food and drink are objects of both trade relations and cultural regard, and as such are likely located at whatever intersections may exist between these two key expressions of human activity. This finding indeed is supported in the Non-Exhaustive List of Cultural Goods and Services in the UNESCO First Draft Convention, in which "culinary traditions" were included under the heading of "cultural activities" 69 (The list has been deleted from the Second Draft Convention. $)^{70}$ This approach makes food-and hence GIs for food and wine products-an appropriate focal point for the discussion of the trade-culture nexus. What, then, are the functional and cultural arguments and justifications for utilizing GIs in the regulation of the trade-culture relationship in the context of food and drink?

give up black bread in order to eat rice instead! Or the people of China, to give up rice to eat black bread! Such food habits are so close to the core of what culture is that they sometimes function almost like language. As with language, on many occasions people define themselves with food; at the same time, food consistently defines and redefines them."). Another dimension of the food-language relationship/analogy, is the role of the language of food as an indicator of the relative weight and characterization of food or particular foods in local culture. Those interested in this aspect will find much to explore in REBORA, supra note 62. For example, as noted in the translator's preface, Italian has sixty specifically named words for pork or beef sausage, where English has only sausage and salami. Id. at ix.

67 Mintz, supra note 61 , at 26.

68 David Bell \& Gill Valentine, Consuming Geographies: We ARE Where WE EAT (1997).

69 UNESCO First Draft Convention, supra note 4, annex I.

70 UNESCO Second Draft Convention, supra note 4. 


\section{SECONDI: THE ROMANCE OF REPUTATION - THE CASE FOR CULTURAL PROTECTION THROUGH GEOGRAPHICAL INDICATIONS}

\subsection{An Informal Positive Theory of the Law and Economics of Cultural Protection through GIs}

Before elaborating on the cultural justifications for GI protection of food and wine products as reflected through the dimensions of production, consumption, and identity, it is helpful to examine the legal and economic functions of GIs in this cultural respect.

As already mentioned, the drive for protection of cultural assets can take virtually any form of protectionist international economic policy. ${ }^{71}$ This is an almost superfluous observation: insofar as trade-related policy-cultural or otherwise-and regardless of its economic merits, seeks to shelter production methods, preserve consumption patterns, and prefer "champion" products of identity, it is clearly diametrically opposed to the market logic of free trade theory. Liberal free trade essentially sees cultural communities as groups of consumers like any other, which should be permitted to determine the market price or added-value of the cultural content of each widget, in comparison to the freely available, culturally-indifferent alternatives. Where the community attaches sufficient economic value to the preservation of its real, alleged, or imagined cultural practices and icons, the local cultural widget will prevail. However, where the economic value of the cultural charge of the widget is low-in terms of the worth of its production and consumption peculiarities and its impact on identity, all as determined by its local market-the market share of the widget may well decrease, enacting significant changes in production and consumption and reflecting uncompetitive "identity" values. In some cases, the cultural widget may even be excluded entirely from the market-the economic forerunner of cultural extinction. 72

71 See Footer \& Graber, supra note 40 , at $122-26$, and the text accompanying note 40 (listing examples of the various devices employed in the name of cultural protection).

72 One could well conceive of cultural widgets as public goods, and of such cultural sacrifices to the market as "tragedies of the commons," in the sense that private preferences determine the demise of the "cultural" widget. But if preferences were pooled, it would persist. See generally Garrett Hardin, The Tragedy of the Commons, 162 SCIENCE 1243 (1968) (discussing the original 
It is in these instances that economic cultural-protection measures may become relevant. Culture may be highly valued collectively, but if aggregate individual consumer demand cannot independently sustain the cultural widget in the face of noncultural but otherwise functionally substitutable products, the widget's economic survival requires regulatory protection for its preservation. ${ }^{73}$ In the cross-boundary context, the most obviously pursuable measures to this end are protective tariffs and discriminatory taxation designed to preserve current domestic production and consumption methods and patterns. Of course, these may likely contravene the most basic GATT/WTO nondiscrimination disciplines such as Article I of GATT Most-Favored Nation Treatment and Article III of GATT National Treatment, and related rules in regional trade arrangements. This has indeed been the outcome in the relevant jurisprudence. ${ }^{74}$ Moreover, in these leading cases cultural exceptions were not emphasized, reflecting the absence of an explicit general cultural exception in Article XX of GATT.

formulation of the tragedy of the commons in the context of the nuclear race).

${ }_{73}$ The same could be argued about public morals and negatively cultural widgets that offend them, such as gambling services. In this vein, if public morals are indeed publicly held, then arguably they do not need paternalist legislation to uphold them; but see economic analysis suggesting that cultural widgets might be particularly susceptible to market failures in Pierre Suavé \& Karsten Steinfatt, Towards Multilateral Rules on Trade and Culture: Protective Regulation or Efficient Protection?, in ACHIEVING BetTer Regulation OF SERVICES: CONFERENCE ProceEdings 323 (Canberra, Austl., June 26-27, 2000), http://www.pc.gov.au/research/confproc/abros/abros.pdf.

74 For example, the respective taxation schemes of Korea and Japan openly granted significant advantages to the locally distilled rice-based beverage, Soju (in Korea) and Shochu (in Japan), over alternative distilled drinks. Japan-Taxes on Alcoholic Beverages, supra note 16, at 34; Appellate Body Report, Korea-Taxes on Alcoholic Beverages, WT/DS75/AB/R, WT/DS84/AB/R., at 1 (Jan. 18, 1999). In a less overt fashion, Chile's taxation scheme set a low tax rate for the low alcohol category dominated by the local grape distillate, Pisco, and high tax categories for the higher alcohol categories of imported brandies. Appellate Body Report, Chile - Taxes on Alcoholic Beverages, WT/DS87/AB/R, WT/DS110/AB/R (Dec. 13, 1999). All of these taxation measures were found to be non-compliant with WTO rules. In a much earlier GATT case, the target of protection was not local production, but rather local consumption patterns of coffee (presumably for reasons related to inflationary pressures) that were to some extent described as the result of Spanish leisure and food culture. (The Spanish authorities set tariff rates that gave preference to "mild" types of coffee that had previously been purchased by the governmental coffee procurement monopoly.) Report of the Panel, Spain-Tariff Treatment of Unroasted Coffee, I 3.14, L/5135 (June 11, 1981), GATT B.I.S.D. (28th Supp.) at 102 (1981). 
GIs and their purported contribution to cultural preservation enter this arena in a different, roundabout way; they do not have the same blatantly market-restrictive effects of tariff or tax trade protectionism. It must be emphasized that the first function of GIs - indeed, their primary raison d'etre - is not the restriction of international trade with a view towards the safeguarding of culture. Rather, GI mechanisms have been founded on a combined quasi-intellectual property/consumer protection platform. Their initial justification is the prevention of fraud, of "passing off" a good as if it has been sourced from where it has not, ostensibly preventing the dilution of a geographical production area's reputation by low quality-or simply different-quality-produce from another region.75 At this level of analysis, GI requirements should in theory have virtually no effect on the intrinsic value of the GI-protected widget, as they simply inform the consumer of its provenance. In crude neoliberal economic terms, GIs thus could actually be said to promote free trade by facilitating full information, towards perfect market conditions; a cultural widget is simply shielded from non-cultural competition that unfairly uses its GI, permitting consumers to exercise their preferences. In this sense, GI protection needs no additional cultural justification, as it runs with the grain of trade theory and the integration of intellectual property and consumer protection interests and disciplines (however controversial) therein. GI proponents have the ideals of free and informed markets, morally attributable intellectual property rights, and consumer protection on their side; GI opponents or challengers end up in the uneasy seat of protectors of the right to defraud the public unless they can show that the use of the particular GI does not risk confusing

75 This is easily discernable in the language of article 22.2 of the TRIPS Agreement, wherein GIs are intended to prevent "the use of any means in the designation or presentation of a good that indicates or suggests that the good in question originates in a geographical area other than the true place of origin in a manner which misleads the public as to the geographical origin of the good" and "any use which constitutes an act of unfair competition within the meaning of Article 10bis of the Paris Convention (1967)." TRIPS Agreement. art 22.2. The "Paris Convention" is the Paris Convention for the Protection of Industrial Property, Mar. 20, 1883, as last revised at Stockholm, July 14, 1967, 21 U.S.T. 1583, 828 U.N.T.S. 305. The Paris Convention is complemented by the Madrid Agreement Concerning the International Registration of Marks, Apr. 14, 1891, 828 U.N.T.S. 389, and the Protocol Relating to the Madrid Agreement Concerning the International Registration of Marks, adopted June 27, 1989, WIPO Pub. No. 204(E). 
consumers. ${ }^{76}$

This picture is factually and economically incomplete, however, for a number of reasons. First, the basic consumer protection/perfection of information argument does not in itself justify the institution of a legal GI mechanism, whether at the national or international level. A simpler solution would have been a prohibition on misleading labeling, for example, without establishing quasi-intellectual property rights. Implicit in the GI system is the recognition that not all foods are created equal in their right to protection. Some products deserve protection and others do not; this requires a filtering norm that will allow differentiation between them. In WTO law, this norm is found in article 22.1 of TRIPS: "Geographical indications are, for the purposes of this Agreement, indications which identify a good as originating in the territory of a Member, or a region or locality in that territory, where a given quality, reputation or other characteristic of the good is essentially attributable to its geographical origin." 77 Here culture enters as a possible "quality, reputation, or other characteristic of the good" that justifies its GI status. GIs therefore are not just informational; they purport to say something about the specialty of the GI-protected good.

Second, and to some extent as a result, it is often argued that GIs do in fact add value to goods beyond their intrinsic value, particularly when restricted to specific goods and not accorded to all.78 GIs thus serve a value-enhancing or premium-creating role above and beyond their informative function. It is the specialization and monopolization of the GI brand that achieves this, so that some GI-designated food and beverage products may command higher demand and higher prices than undesignated products-regardless of their actual qualitative or even GIindependent reputational merit. A mediocre product may therefore gain additional economic value simply by virtue of having a GI attached to its label. This may be true regardless of whether the GI was relatively unknown previously or widely celebrated. In any event, it is clear that regulatory and legal protection of GIs constitutes a form of governmental intervention and market manipulation that influences prices, market shares,

76 This type of showing is not allowed in the case of extended GI protection to wine and spirits under article 23 of TRIPS.

77 TRIPS Agreement art. 22.1 (emphasis added).

78 E.g., EU Background Note, supra note 25. 
and trade flows. Trade negotiations, transnational or international litigation, and the rules they produce (including, but not limited to, the applicable filtering norm(s)) therefore determine which products will benefit from added GI-endowed value in the market-a dynamic clearly reminiscent of the War of the Two Beans. ${ }^{79}$ Cultural protection enters this debate as an important possible justification for the additional value that GIs grant designated products: cultural widgets are supposedly both worth the extra cost and deserving of government intervention and regulation aimed at preserving culture that adds value. Thus, culture is protected in theory not only by distinguishing cultural widgets from the non-cultural, but by valorizing the cultural expression embodied in the widget and converting it into a commercial premium.

Third, international rules on GIs have in substance gone significantly beyond the basic intellectual property/consumer protection rationale. Specifically, GI-protected wines and spirits have, under TRIPS, been given an enhanced degree of safeguarding. GI protection is to be granted even where there is no need for consumer protection. The regular degree of protection ${ }^{80}$ essentially establishes exclusive rights of GI use through a rebuttable presumption whereby parallel use of the same GI may cause consumer confusion. Where it can be shown that circumstances exist preventing such confusion, or that effective measures have been taken to this end, GI exclusivity may be relaxed. However, the enhanced GI protection of wines and spirits goes a step further - the risk or existence of consumer confusion is formally immaterial to the degree of protection accorded the GI. Products in this category enjoy a near-absolute degree of exclusivity that prevents the use of the GI by others, even when measures have been taken to prevent confusion, such as clear indications of the true geographical origin of the goods in question, the use of the GIs in translated form or "accompanied by expressions such as 'kind', 'type', 'style', 'imitation' or the like" 81 (such as "Port Style" or "Méthode Champenoise").

As mentioned previously, a central negotiation issue in the DDA talks on GIs is the proposed extension of this "enhanced" or

79 See supra note 8 and accompanying text.

80 See TRIPS Agreement art. 22 (describing the level of protection for GIs).

81 Id. art. 23.1. 
"additional" protection beyond wines and spirits. ${ }^{82}$ Such an extension may have considerable economic impact on producers and consumers. Presumably, the value of GIs that have been granted "enhanced" or "additional" protection is higher, since the general marketing costs for brand maintenance are lower under conditions of exclusivity, as are legal and litigation costs for the enforcement of the right (absent the need to confront arguments relating to consumer confusion). Moreover, the added prestige involved in belonging to a higher category of protection may translate into market value. Once again, culture enters the debate as a justification - this time, as a justification for the higher, indeed inflexible, degree of protection. In the category of enhanced GI protection, consumer protection ceases to serve as a rationale 83 and therefore needs to be replaced by another justification. Culture, among other components of reputation, fulfils this role. Thus, in the area of enhanced GI protection, cultural concerns may act as the foundation not only of the additional degree of protection, but of the entire construct of GI protection of the relevant goods.

In sum, even taking into account the strong consumer protection motivation of the GI system de lege lata, the preservation of culture is a necessary (if not the most debated) component of the argument for GI protection in its existing and potentially enhanced forms. In legal and economic theoretical terms, the cultural issue can be identified in the consumer protection argument itself. It explains, at least in part, why the GI system has been established and the way it has been designed, and it is of critical importance in the justification of the "enhanced" level of GI protection which has disentangled itself of the original consumer protection rationale.

What, then, are the aspects of culture purportedly protected by GIs? Let us follow the trade-related cultural dimensions previously identified, insofar as they may be separated: production, consumption, and identity.

82 See supra text accompanying note 20.

83 It might be said that the risk of consumer confusion is still the basis for enhanced GI protection, with the stricter rules applied so as to regulate the redistribution of costs between GI holders, non-GI producers, and consumers. In practice, however, the effect is to remove the consumer protection rationale of such GIs. 


\subsection{The Culture of Production: Terroir, Traditional Methods of Production, and Rural Culture}

The culture of production that some GI proponents consider embedded in food and wine products is multifaceted and relates to several (mainly Eurocentric) ethos-like dimensions of common perceptions of these products' agricultural basis.

A central anchor in this respect is the difficult, mystified concept of terroir-a uniquely French term that has gained a following elsewhere in Europe and throughout the world. In its narrowest sense, terroir refers only to the physical environmental aspects of the geographical origin of a foodstuff or wine: soil, lay of the land, elevation, climate, and related factors. For terroir advocates, each finished agricultural or viticultural product should be a faithful expression of its geography. Better quality products will emerge from plots of land of superior quality and better endowments; in any event each product will inimitably reflect its growing conditions. It is thus necessary that different crops, cheeses, and wines be distinguishable from each other and associated with their geographical origin. (This is also a component of the "culture of consumption" that I will revisit shortly.) In this respect, the idea of terroir forms one of the bases for the GI legal mechanism, regardless of culture, providing a technical conceptualization of the link between food and place of cultivation. Moreover, on the production side, philosoph(iz)ers of terroir expand the term to include the human environment ${ }^{84}$ or even a mental dimension - a link between producer and consumer that runs through the product and its unique terroir-based qualities. At minimum, this implies a noninterventionist, terroirdriven culture of production: less human manipulation, more respect for the earth's independent capacity to express itself through its fruits, and adequately satisfy human tastes, desires, and wants. Thinking about terroir on a more sophisticated level, however, just as nature and humankind have through progressive efforts established and confirmed which crops do best in which terroir, farmers and winegrowers have discovered the "best" winemaking practices for each area of production. Terroir is thus the epitomic opposite of globalization: an exemplary reflection of

84 See FANET, supra note 9, at 10 (defining terroir as "an umbrella term for a subtle interaction of natural factors and human skills that define the characteristics of each wine-growing area"). 
place and people. As such, it arguably deserves protection, even enhanced protection, from commercial forces that threaten to compel homogenization and obliterate local terroir-ist cultures of production. GIs are ostensibly a targeted way of achieving this, since they grant each terroir, as officially defined and delimited, a separate, legal source of protection.

An important part of the narrative of terroir is the celebrated distinction between "Old World" and "New World" food production sensibilities. In much food and wine historiography, the production cultures of Europe, as a leading example, are the result of centuries (even millennia) of intimate human interaction with the earth that is absent in the Americas or Australia:

viticultural practice in the Old World-choice of sites, growing techniques and appropriate vines - is based on a trial-and-error process dating back at least two thousand years ... New World viticulture, by comparison is still in its infancy. It officially started 400 years ago but only really got going a century and a half ago and much more recently in some countries. 85

This perception is most salient in the wine industry, but it also appears in the production of cheeses, oils, herbs, mushrooms, truffles, and in the culinary arts. Old World sensitivities are therefore presumed more vulnerable to global cultural tendencies, and their production peculiarities should be humored and protected. Of course, from a critical standpoint, there is something offensive about this approach - the New World is not new, and there existed a thread of indigenous traditional human interaction with its terroir in many locales before European domination either brutally cut it or shifted its course.

Nevertheless, terroir-based GI designation has gained significant support and emulation in New World countries. ${ }^{86}$ The

85 See id. This truism is echoed in WILSON, supra note 9, at 6.

86 Appellation systems for geographical classification of wines exist in Australia, New Zealand, South Africa, Canada, the United States, Chile, and Argentina. See Micheal Maher, On Vino Veritas? Clarifying the Use of Geographic References on American Wine Lables, 89 CAL. L. REV. 1881, 1885 (2001) ("Today, every major wine-producing nation has a regulatory regime for wine labeling that incorporates geographic delimitations of grape-growing regions."). Where there is no such legal regulation, wineries in emerging wine countries (e.g., Israel) voluntarily label their produce with regional designations. See DANIEL Rogov, ROGOV'S GUIDE TO ISRAELI WINES 2005, at 10-12 (2004) (discussing Israel's 
EC-GIs case, although formally a dispute between Old and New World producers, ${ }^{87}$ was not about the delimitation of the concept of GIs, but rather about the equality of New World and Old World GIs and the conditions of their legal protection. In negotiations on the extension of enhanced GI protection beyond wines and spirits, although a New/Old World dividing line is discernable, some developing countries have also adopted the rationale of the preservation of traditional cultures of production. They are asserting their Old-ness, where they might have been regarded as New World producers from a narrow European perspective. ${ }^{88}$

At any rate, this discussion leads to a cultural aspect of production that need not rest on acceptance of the validity of terroir, old or new: the preservation of traditional production practices and methods. Even if one remains skeptical of the numinous link between land, fruit, and local culture, it is indisputable as a dry fact that different regions grow different crops and varieties, and process them employing different production methods, down to the resolution of particular pieces of equipment. ${ }^{9}$ In many cases these practices are idiosyncratic, objectively anachronistic, rooted in social, technological, or historic circumstances that once prevailed but have since disappeared. Under open market conditions they may easily vanish, without necessarily altering the qualities of the finished product, ${ }^{90}$ although

voluntary regional designations).

87 See supra text accompanying note 22.

88 See Council for Trade-Related Aspects of Intellectual Property Rights, Communication from Bulgaria, Cuba, Cyprus, The Czech Republic, The European Communites and Their Member States, Georgia, Hungary, Iceland, India, Kenya, Liechtenstein, Malta, Mauritius, Pakistan, Romania, The Slovak Republic, Slovenia, Sri Lanka, Switzerland, Thailand and Turkey, \6, IP/C/W/353 (June 24, 2002) (citing traditional production methods as one of the components of a reputation relevant to GI protection in India, Kenya, Mauritius, Sri Lanka and Thailand).

89 As a figurative example, consider Le Têtu ("the stubborn one"), a wine press made of 1000-year-old oak beams, erected at the historical and prestigious Burgundy vineyard Clos de Vougeot, reportedly still in operation. WILSON, supra note 9 , at 178 .

90 For example, foot treading in lagares (open fermentation tanks) is a traditional method still used in the making of port wines in the Oporto region of Portugal, purportedly contributing to the character of the wine in a manner not replicable by regular mechanical presses. Special robotic lagares that simulate the foot treading action have recently been developed and are replacing some of the traditional foot treading. Larry Walker, Graham's Ports Uses Robotic Lager to Crush Grapes, WINE \& VINES, Feb. 2003, available at http://www.findarticles. com/p/articles/mi_m3488/is_2_84/ai_98055538. 
as a result the associated culture of production might be eradicated.

Hence, some production methods are regulated legally. Many national systems of GI regulation are based on the original French Appellation d'Origine Contrôlée ("AOC") system. In these systems, a product is eligible for GI (or similar) protection not only by virtue of its physical place of production, but also by its compliance with a set of (sometimes strict) criteria relating to content (grape varieties in wines and spirits; $; 1$ permitted varieties of walnuts; $; 2$ types of milk in cheeses ${ }^{93}$ ) and methods of production (yields per hectare; 94 harvesting dates and time in oak barrels for wines; detailed methods for the manufacture, aging and packaging of Balsamic Vinegar of Modena). ${ }^{95}$ Rules such as these are to a large extent quality-oriented, aiming to set a minimum quality level for GI-worthy products. But quality here has a double meaning;

91 See e.8., Décret du 5 Mai 1982, Définissant l'Appellation d'Origine Contrôlée [("AOC")] "Faugères," Journal Officiel de la République Française [J.O.] [Official Gazette of France], May 14, 1982, p. 4609, as modified by Décret simple du 21 juillet 2000, Journal Officiel de la République Française [J.O.] [Official Gazette of France], July 25, 2000, p. 11451, Décret simple du 05 février 2003, Journal Officiel de la République Française U.O.] [Official Gazette of France], February 12, 2003, p. 2592, and Décret simple du 23 février 2005, Journal Officiel de la République Française [J.O.] [Official Gazette of France], February 25, 2005, p. 3266 (defining in detail the relative part of each of the allowed varieties in the Faugères AOC red blend).

92 Under article 4 of the Décret $n^{\circ} 96-621$ du 10 Juillet, 1996, Relatif à l'Appellation d'Origine Contrôlée "Noix de Grenoble," the AOC Noix de Grenoble for walnuts (which was established in 1939) may only apply to walnuts of the three varieties, Franquette, Mayette and Parisienne. Décret no 96-621 du 10 juillet 1996 relatif à l'appellation d'origine contrôlée "Noix de Grenoble," art. 4, Journal Officiel de la République Française [J.O.] [Official Gazette of France], July 13, 1996, p. 10586. This has been recognized under EC legislation, as have the varieties that may be included in U.S. walnut mixtures and products labeled under the label "California Walnuts." Commission Regulation 80/2003, Amending Regulation No. 175/2001 as Regards Certain Mixtures of Certain Varieties of Walnuts in Shell, Officially Defined by the Producing Country, 2003 O.J. (L 13) preamble (2).

93 See, e.g., Paraskevi Dimou, Les Dénominations des Fromages (Sept. 2002) (unpublished D.E.A. dissertation, Université Robert Schuman Strasbourg III), available at http://www.ceipi.edu/pdf/memoires/Memoire_Demou.pdf (describing the history and practice of cheese appellations).

94 See, e.g., Décret du 20 octobre 1997 relatif à l'appellation d'origine contrôlée "Chinon," Journal Officiel de la République Française [J.O.] [Official Gazette of France), October 22, 1997, p. 15353 (describing how wines from Chinon, the land of Rabelais, can only bear the name Chinon if the wineries conform to certain hectoliter/hectare yields).

95 For details, see the website of the Consorzio Produttori Aceto Balsamico Tradizionale di Modena, http://www.balsamico.it/ing/prodotto.html (last visited Dec. 3, 2005). 
quality also means living up to traditional standards and reputation. Thus, GI rules also strive to preserve a certain historical purity of production.

As such they present a cultural rationale, based on traditions of production, for the maintenance of GI protection. This is a rationale that is particularly well accepted in public opinion, mainly in Europe. Reportedly, in two consumer surveys taken in 1994 and 1996 of a 16,000 EU citizen sample, 17\% considered the protection of traditional methods of production to be one of the two most important functions performed by GIs/Appellations of Origin. ${ }^{96}$

More broadly, like other forms of agricultural protectionism, GIs may be construed as necessary for the preservation of the farm culture of production in general, without a necessary link to specifically idiosyncratic, localized production methods, or particular terroir. Concern for the vanishing peasant ${ }^{97}$ and associated rural culture has accompanied western industrialization and rationalization of agricultural practices for more than a century. ${ }^{98}$ Notably, in some cases this argument only seeks to preserve a lifestyle of agricultural productive activity as an expression of family and community culture, regardless of quality benefits. ${ }^{99}$ Indeed, this is an argument that relates to the culture of production, but borders also on the culture of identity, linking the product whose existence may depend on GI protection with a

96 Council for Trade-Related Aspects of Intellectual Property Rights, Minutes of Meeting Held in the Centre William Rappard on 25-27 and 29 November, and 20 December 2002, I 141, IP/C/M/38 (Feb. 5, 2003).

97 See generally HENRI MENDRAS, THE VANISHING PEASANT: INNOVATION AND CHANGE IN FRENCH AGRICULTURE (Jean Lerner trans., MIT Press 1970) (1967) (exploring the effects of modernization on French agriculture).

98 See, e.g., GABRIEL TARDE, FRAGMENT D'Historie FutURE [FraGmENT OF FUTURE HISTORY] (Slatline Reprints 1980) (1896) (discussing the diminished role of rural agriculture in modern society).

99 The epigraph of this Article quotes a winegrower in the Languedoc belligerently defending the merits of French wine culture. The truth is that the Languedoc is the largest bulk-wine producing region in France, not particularly renowned for quality (with more recent and notable exceptions). See KERMIT LYNCH, ADVENTURES ON THE WINE ROUTE: A WINE BUYER's TOUR OF FRANCE 73-74 (1988) (citing ALEXIS LICHINE, ENCYCLOPEDIA OF WINE AND SPIRITS (1970 ed. and later editions)). The culture that the winegrower is adamantly trying to defend is a culture of labor, not quality or terroir. In 1967, it was reported that in the Languedoc "67 percent describe the good wine grower as one who knows how to work hard, while only 9 percent say he is one who has good grapevines, and 5 percent one who makes good wine." MENDRAS, supra note 97, at 143. 
cultural way of life that ostensibly may be crushed by the wheels of global consumerism. 100

\subsection{The Culture of Consumption: Traditions of Discrimination in} Taste and Time

In granting market advantages to particular foods and wines, GI protection may also contribute to the preservation of cultures of consumption, not just production. The most obvious such case arises when on one hand there is an equivalence or dependence between local traditions of production, and on the other hand local traditions of consumption in the same place. That is where local types of food or beverage are produced, as they are, primarily or even exclusively for consumption by the producers themselves and their households and immediate communities, in accordance with local tastes. Competitive exposure to cheaper, better, non-local alternatives might risk the survival of local production, by shifting consumption patterns and producing changes in local traditions. As much as this seems a specialized scenario, one can more generally imagine a cultural, terroir-minded defense for unabashed pro-local consumption traditions, in which it is argued that there exists a culture of consuming local food and beverage products, because they are local. This may be justified by objective quality factors (such as freshness of produce, edified as a cultural preference) or by the ethereal existence of a mental or symbolic factor of consumerism, linking place of consumption with place of production. ${ }^{101}$ At its most abstract (and most protectionist), however, the argument would simply be that there is cultural merit in preserving the dependence of consumers on the fruits of the very land where they reside, whether they are themselves producers or not. This is, however, perhaps more appropriately an argument couched in terms of local identity, to which I will turn shortly.

Moreover, the overtly discriminatory nature of such narrow

100 See generally Anne Tyler Calabresi, Vin Santo and Wine in a Tuscan Farmhouse, in CONSTRUCTIVE DRINKING: PERSPECTIVES ON DRINK FROM ANTHROPOLOGY 122, 122-25 (Mary Douglas ed., 1989) (depicting in a particularly romantic style the traditional lifestyle that centers on wine production, warts and all).

101 This completes the trinity of the ultimate ethos of terroir-land, producer, consumer. See supra text accompanying note 84 for a discussion of a mental dimension of terroir. 
consumption-culture arguments, however plausible (or not), make them extremely difficult to reconcile with basic GATT/WTO principles. ${ }^{102}$ Indeed, in terms of simple economic analysis, if the preservation of such "neighborhood" production-consumption cultural networks is indeed so important to local tradition or culture, one would expect this sentiment to overcome external market pressures, even at greater cost to consumers. ${ }^{103}$ The rejoinder would be that while these cultural arguments do not, indeed, give good reason for tariff or tax preference, they do justify accurate geographical-source labeling, permitting the public to choose between local and foreign or ex-regional produce. Thus, the informative function of GI protection may arguably serve a purpose in the context of the culture of consumption.

An additional, broader justificatory basis may be supplied, however. One also reliant on the informative function of GIs, if it is accepted that there do exist local "traditions of discrimination" in the positive cultural sense of particularity, preference and discernment, not in the negative trade law sense-that are not chauvinistic and trade-protectionist because they do not prefer (at least not exclusively) local products. In these traditions, a local consumer-culture market preference exists for food and wine products of specific geographical sources. This preference is based on traditional perceptions of the type of production practiced at the product's source, or the quality of the finished product, and, of course, on real distinctions between different products.

For example, England produces very little wine itself, much less of viable quality or distinction. ${ }^{104}$ Yet historically, England (or

102 These principles include: the national treatment and the most favored nation principles of GATT Articles I, III, and potentially XIII; non-discrimination rules in the TRIPS Agreement and (at least with regard to distribution services) GATS; and the general exceptions of GATT Article XX and GATS Article XIV mentioned above. See infra Section 5.3 for more discussion of the general exception rules.

103 But again the possibility of market failure arises, in the same way that it did with regard to the discussion of the tragedy of the commons. See supra note 66 and accompanying text (bemoaning the potential negative effects of private, individual preference on public goods).

104 It is not a matter of coincidence that Ricardo's famed exposition of the principle of comparative advantage compared England's winemaking faculties unfavorably with those of Portugal. See David RICARDO, THE PRINCIPLES OF POLITICAL ECONOMY AND TAXATION 76 (Lloyd Reynolds and William Fellner eds., Richard D. Irwin, Inc. 1963) (1817). However, in the current era one must distinguish between "British Wine," usually made from low quality grapes that must be imported from any place on earth to be vinified in Britain, and "English 
more precisely, influential social classes in England) has demonstrated an independent consumption-culture of discriminating taste. The English-not the French, Germans, Portuguese, or Spanish - have been responsible for the production cum cultural edification and reputational establishment of some of the Old World's greatest wine regions, such as Bordeaux,105 Oporto, ${ }^{106} \mathrm{Jerez}^{107}$ and the Rheingau. ${ }^{108}$ Though individual English

Wine," wine made from grapes grown in England. An English specialty of repute is Méthode Champenoise sparkling wine of Nyetmber, a small winery in West Sussex that prides itself as being "Distinctly Anglais!", deliberately casting itself against the exclusive tradition of Champagne. For further background information, see Nyetimber Wines, http://www.nyetimber-vineyard.com (last visited Dec. 3, 2005).

105 Bordeaux was established as an important wine region in the twelfth century with the marriage of Eleanor of Aquitaine to Henry Plantagenet, future Henry II of England. ROD PHILlIPS, A SHORT HISTORY OF WINE 87 (2001). The mouth of the Gironde, just across the channel, provided easy access to the large English fleet and made Bordeaux the ideal source of wine to satisfy the English taste for "claret." DEWEY MARKHAM, JR., 1855: A HISTORY OF THE BORDEAUX CLASSIFICATION 39-40 (1998) (recognizing English demand for Bordeaux's specialty wines and ease of access to the region by sea).

106 The wines of Port (Oporto) flourished in the eighteenth century because of increased English demand brought on by unreliable supply from Bordeaux due to French-English strife; this was encouraged by the 1703 Treaty of Methuen, which granted Portuguese wine lower duties than those of France and Germany. See Phillips, supra note 105, at 129-30, 137 (discussing the French-English political problems that led to increased Portuguese exports of wine to England in the late 16th and early 17th centuries); see also TOM STEVENSON, THE SOTHEBY'S WINE ENCYCLOPEDIA: THE CLASSIC REFERENCE TO THE WINES OF THE WORLD 334 (4th ed. 2005) (noting the pro-Portuguese wine import terms of the Methuen Treaty of 1703).

107 The truly unique wines of Jerez, known in England as Sherry, were often mentioned in Shakespearean plays and were coveted by the English even by nonpeaceful means in the early seventeenth century. See e.g., WILLIAM SHAKESPEARE, THE SECOND PART OF HENRY THE FOURTH act 4, sc. 3 ("Hereof comes it that Prince Harry is valiant; for the cold blood he did naturally inhereit of his father, he hath, like lean, sterile and bare land, manured, husbanded and tilled with excellent endeavour of drinking good and good store of fertile sherries, that he is become very hot and valiant."). Failure to take Cadiz in 1625, coupled with the shortage of Bordeaux wine, brought on a wave of English investment in Jerez; to this day, many of the main shippers of Jerez go under old English or Irish names, such as Garvey's, Duff \& Gordon, Williams \& Humbert, Sandeman and Osborne. See generally JULIAN JEFFS, SHERRY (5th ed. 2004) (1961) (explaining the history of sherry in more detail).

108 The white wines of Hochheim in the Rheingau, known at all times under the colloquialism of "Hock," were held in high esteem in eighteenth and nineteenth century England. See STEVENSON, supra note 106, at 349 (noting the popularity of Hock in 19th century England). The wines' popularity was temporarily supported by a Germanic fad related to Prince Albert's heritage. See German Wine Notes: History, http://www.winetours.co.uk/wine-notes- 
entrepreneurs facilitated these developments on the production side, arguably as early globalizers, ${ }^{109}$ the increase in the importation of wines has been consumer-driven, propelled by English tastes and capitalizing on an English consumer culture of discrimination.110 At least in theory, such a local culture of discrimination is the opposite of global homogenization, of "McDonaldization." The preference for products sourced from specific locations rests, of course, on a confidence in the quality and durability of the production in those locations, and on a belief that food or wine from a given location is guaranteed to reflect a certain, desirable style, or quality. The culture of consumption of one region is thus inextricably linked to the cultures of production of other regions. Moreover, it is self-evident-particularly because the qualities and characteristics of food and drink products require their consumption in order to be appreciated-that for such a culture of consumption to survive, consumers need prior accurate information on the geographical source of products, and to this end GIs may serve a positive purpose. Here, the cultural justification is in harmony with the consumer protection rationale.

Ultimately, cultures of discrimination can be generally couched in nigh post-modernist terms advocating geographical transparency: "Consumers these days want to know what they are eating, where it comes from and how it is produced."111 However vague that argument may be, it is perhaps as relevant to the debate on genetically modified organisms as it is to the debate on the extension of GI protection.

Consumer practices may have additional supporting-some

germany.htm (last visited Dec. 3, 2005) (crediting Hock's popularity in England in part to Queen Victoria's marriage to Prince Albert, a native of the Rhineland).

109 For example, the wine industry on the Portuguese island of Madeira was in fact founded virtually from scratch by the English. Madeira Wine, http://www.madeira-web.com/PagesUK/wine-uk2.html.

110 As a historical footnote recording both geographical interest and discriminating taste, on April 10, 1663, Samuel Pepys noted in his diary that he had drunk "a sort of French wine, called Ho Bryan, that hath a good and most perticular [sic] taste that I never met with." 4 SAMUEL PEPYS, THE DIARY OF SAMUEL PEPYS 100 (Robert Latham \& William Matthews eds., Univ. of Cal. Press 1971) (1663). Chateau Haut Brion, the wine referenced here, is still a highly prestigious first growth Bordeaux wine today. See e.g., ROBERT M. PARKER, JR., THE WORLD's GREATEST Wine Estates: A MODERN Perspective 126 (2005) (referring to the history of Chateau Haut Brion as one of the "oldest and most illustrious of any vineyard").

111 FANET, supra note 9, at 10. 
might say central-aspects that focus on particular traditional habits. For example, the culture of serving meals or courses of meals with the wines that are most complementary from a sensory perspective. Some of such food-wine pairings have become staples of consumption; 112 their preservation arguably requires continued and perhaps extended accurate geographical labeling and, hence, GI protection. Traditions also sometimes match foods or wines with festive, seasonal, or other special occasions. ${ }^{113}$ In these cases, the use of the most prestigious or desirable ingredients, or the opening of the most celebratory type of beverage may have a social meaning of cultural dimensions. Again, we are brushing with the culture of identity, but it is nevertheless an identity expressed through patterns of consumption.

\subsection{The Culture of Identity: Local Champions and Cultural Landscapes}

On this level of analysis, GIs arguably protect the integrity of national food icons that construct identity. Food plays an important part in defining locales, regions, and nations. Guidebooks and textbooks will normally dedicate at least a few pages to the food and drink that characterizes a particular region or country, and the shelves of the cooking sections of bookstores are often geographically categorized. A distinctive kitchen-like a flag, a currency, or a dialect-serves to distinguish one nation or region from others to the point that the development of an independent cuisine may be seen as an integral part of any nationbuilding project.114

112 For example, Chablis and oysters, Rioja and lamb, Port and Stilton.

113 See, e.g., Mary Anna Thornton, Sekt versus Schnapps in an Austrian Village, in CONSTRUCTIVE DRINKING, supra note 94, at 100, 104-108 (discussing examples of two drinks, sekt and schnapps, that carry great social meaning, polarizing social occasions into planned versus spontaneous celebrations).

114 For a universally acknowledged assertion of Italian culinary distinction enmeshed in the making of Italy in the last quarter of the nineteenth century, including the reclaiming of French traditions as originally Italian (e.g., Béchamel sauce being none other than the Italian balsamella, which has its origins in ancient Rome), see generally PELlegrino ARTUSI, LA SCIENZA IN COCINA E L'ARTE DI MANGIARE BENE [SCIENCE IN THE KITCHEN AND THE ART OF EATING WELL] (Murtha Baca trans., 2003) (1891). For a contemporary continuation of this discussion, see generally GIUliano BugIalli, THE Fine ART Of ITALIAN COOKING (3d ed. 1990), which asserts Italian (or rather, Florentine) culinary supremacy by demonstrating how French cuisine was significantly influenced by Italian traditions and knowledge brought by Caterina de' $^{\prime}$ Medici and her entourage from Florence when she moved to France following her political marriage to Henri II of France 
Ultimately, where singular traditions are absent or incoherent, the quest for distinction may rely solely upon the use of locally sourced ingredients or products, 115 regardless of how unusual or remarkable they may be, and so these too are assimilated as components of identity. In well-established food cultures, local produce is unabashedly put on a pedestal. In both Piemonte and Perigord, the locals will argue the superior quality of their truffles and sneer at that of Himalayan truffles. Some Spaniards regard their Cítricos Valencianos with national pride, just as the farmers of Prince Edward Island adulate their new potatoes, or the Italians their Chianina beef.

It is not pride alone at stake; food or drink, such as the poultry of Bresse ${ }^{116}$ or sparkling wine of Champagne, ${ }^{117}$ may be adopted as a national symbol or even as personifying the country, as with these products in France. ${ }^{118}$ The international exclusivity of usage of the geographical term is thus perceived as imperative for the preservation of a part of national identity. The appropriation of the name of a foodstuff or beverage by a nation can even give rise to international disputes that stem from struggles for identity, such

in the sixteenth century. Moreover, the role of the kitchen in nation-building has many other expressions. See, e.g., Richard R. Wilk, Food and Nationalism: The Origins of 'Belizean Food', in FOOD NATIONS: SELLING TASTE IN CONSUMER SOCIETIES 63, supra note 7.

115 The creative use of local ingredients becomes, for some, the popular test for the metal of an emerging local kitchen, such as that of Canada: "The debate swirls: is there a Canadian cuisine? One that uses local ingredients in imaginative ways to produce a distinctive, indigenous culinary style?" Don Douloff, Delicious Cancon Chez Metropolis, EYE WEEKLY, Apr. 16, 1992, at 30, 30, available at http:/ / www.eye.net/eye/issue/issue_04.16.92/foodanddrink/ fo0416.htm.

116 The poultry of Bresse (Poulet de Bresse AOC) is physically recognizable as a Tricolor, with red crest, white plumage and blue feet. By law, the chickens must also wear a Tricolor badge at the base of their neck and be packed under a Tricolor etiquette. General Information: How to Recognize "Bresse Poultry," http://www.colorline.fr/pouletbresse/ang.pdf (last visited Nov. 9, 2005).

117 "Within France, champagne has been seen as an embodiment of the national spirit .... 'The wine resembles us, it is made in our image: it sparkles like our intellect; it is lively like our language."' GUY, supra note 8, at 1-2 (quoting Adolphe Brisson, Preface to ARMAND BOURGEOIS, LE CHANSONNIER DU VIN DE CHAMPAGNE EN 1890 (Chalon-sur-Marne, Martin Frères 1890)).

118 In the French context, one might add the truncated, pyramid-shaped cheese of Valençay, by legend the result of Napoleon's rage on his unhappy return from Egypt. STEVE JENKINS, CHEESE PRIMER $92-93$ (1996) (attributing the cheese's traditional shape, a pyramid with the top taken off, to the region's desire to please Napoleon, who was planning a visit after returning from an unsuccessful campaign in Egypt). 
as the longstanding quarrel between Peru and Chile over Pisco, in which each party would appear to feel stripped of a national symbol if recourse to the term were not restricted.119 GIs can therefore be seen as guardians of local identity, and as such, bulwarks against globalized homogeneity.

Identity may also underpin arguments for GI protection for foods when it is deemed necessary for the maintenance of the cultural landscape that forms part of the character of a region or nation; 120 the UNESCO Draft Convention would have policies aimed at preserving and safeguarding cultural landscapes recognized as "Cultural Policies." 121 This concept may be, as already indicated, intimately linked to the cultures of production that determine the landscape, but formulated as a separate argument. It is not the production that is being protected, but the environment that it generates. ${ }^{122}$

\section{CONTORNI: MARKETS AND TRADITION-SOME CONTRARY ECONOMIC AND CULTURAL REALITIES OF THE FOOD AND WINE TRADE}

\subsection{Can GIs Actually Prevent Market-Induced Changes to Culture?}

Against the backdrop of these seemingly compelling arguments for cultural protection through the instrument of GIs, it

119 See Pisco Liqueur Dispute between Chile and Peru, Trade \& ENV'T Database, (PISCO), http://gurukul.ucc.american.edu/TED/PISCO.HTM, ("Pisco is as Peruvian as llamas and arroz con pollo .... Peruvians hold a deep-seated national pride in pisco, which ... [they] have been drinking at parties and rowdy peasant festivals for more than 400 years .... To make real pisco, you have to take your shoes off, crush the grapes and let it ferment in clay bottles. In Chile they make something called pisco, but it doesn't taste as it should."). This, of course, may make it impossible to draw bright-line distinctions between the culture of identity and the cultures of consumption and production, since Peru's background sentiments also relate to the role of pisco in consumption traditions:

120 "Cultural landscape" is "a geographic area (including both cultural and natural resources and the wildlife or domestic animals therein), associated with a historic event, activity, or person or exhibiting other cultural or aesthetic values." U.S. DEP'T OF THE INTERIOR, THE SECRETARY OF THE INTERIOR'S STANDARDS FOR THE TrEatMent OF Historic PROperties WITH Guidelines for the TREATMENT OF Cultural Landscapes 4 (Charles A. Birnbaum \& Christine Capella Peters eds., 1996).

121 See UNESCO Draft Convention, supra note 4, annex II, I 3.

122 For a detailed study of the ways in which viticultural practices form different cultural landscapes, see generally DAN STANISLAWSKI, LANDSCAPES OF BaCCHUS: THE VINE IN PORTUGAL (1970). 
is not necessary to speculate about the effect of GIs on the preservation of traditions of production, consumption, and identity. In Europe, GIs have been legally regulated and enforced at varying degrees since the early decades of the twentieth century, in some cases from the mid-nineteenth century, and - in other rarer cases-even the eighteenth century, ${ }^{123}$ particularly with regard to wine. There exists, therefore, sufficient historical as well as current empirical material to examine as a living, regulatory laboratory.

In this section I will present a (non-exhaustive) series of phenomena in particular real cases that demonstrate the contrary ways in which GIs have proven ineffective in conserving culture and safeguarding cultural diversity. Short of undertaking a comprehensive study that would overstay the welcome of this paper's menu, I would submit that these instances are in fact not exceptional but rather representative of the limits of GI-based cultural protection. If there is a general theme to these examples, it is that the market forces involved in the food and wine industries-commodity markets, production markets, labor markets, corporate markets, and indeed, as we shall see, GI markets - are so pervasive that GIs cannot in and of themselves, as legal agents, prevent the market influences on local culture that lead to degrees of cultural transformation and international cultural homogenization.

4.2. The Culture of Production: Markets Change Cultures of Production Despite GIs, Even When Methods Are Regulated

A first proposition along these lines is that local traditions and cultures of production that benefit from GI protection nevertheless change when markets cause them to, and remain constant when markets cause them to. The safeguarding of cultural diversity is thus at the mercy of market forces, with or without legal GI protection. This happens not only with regard to production methods that are unregulated and legally free to change with consumers' demand or producers' creative requirements, but in some cases also when production methods are stringently regulated by the laws establishing the GI itself.

A prominent example is the evolution of competing styles of winemaking in important wine appellations in Europe since the 1980s, usually demarcated along "traditional" vs. "modern" or

123 See infra note 129 and accompanying text. 
"international" lines. One aspect of this divide is the use of oak barrels in determining a wine's body, flavor, and overall character. While many national wine appellation laws set minimum periods that the wine must age in oak barrels before it may be bottled, they do not determine several additional dimensions of oak aging, such as the type of oak to be used (e.g., French, American, or Slavonian); the size of barrels (large 30 hectolitre vats or relatively small 225litre barriques); the age of the barrels (new or used, and the percentage of new barrels to be employed); and the degree of toasting the oak undergoes during cooperage.124 Each of these variables can significantly affect the organoleptic qualities of the finished wine. ${ }^{125}$ These and other technical oenological flexibilities allow for creativity and personal stylistic expression by winemakers, as well as modernization. Moreover, they have also allowed "new wave" winemakers to depart appreciably from winemaking practices that although unregulated by statute were considered by previous generations as traditional and representative of local sensibilities.

To be sure, in many locales the innovation has been driven by quality considerations aiming at better market access and higher prices: prior traditions were sometimes the upshot of years of wine production whose unscrupulous main goal was quantity and cost-effectiveness, resulting in insipid bulk-products. Changes in production methods have in part been aimed at changing this scene. Yet in other cases, quality, as well as local typicity, ${ }^{126}$ was achieved using the old traditional ways, albeit more dependent on unpredictable annual vintage conditions. There the more recent

124 See, e.g., Tom Maresca, Spotlight on Barolo, THE WINE NEWS, Oct.-Nov. 2002, at 30, available at http://www.thewinenews.com/octnov02/cover.html (showing that while new technology has created differences between Barolo winemakers over the size and age of the barrels, they are both known as Barolo wines) (last visited Nov. 16, 2005).

125 Similarly, many wine appellation rules do determine minimum alcohol levels in the finished wine, but not maximum levels. While earliest harvest dates may be mandatory, the minimum or maximum sugar ripeness at harvest of grapes intended for dry wines is usually set by each winemaker. Duration of maceration and types of yeasts are also usually not regulated. The combination of these factors allows for considerable flexibility in the degree of alcohol in the finished wine.

126 Typicity is a "[w]inetasting term used to indicate the degree to which a wine is typical of its origins - its variety, geography, and sometimes vintage." FOGWELL'S GUIDES, WINE GLOSSARY: TYPICITY (2001), http:/ / www.answers.com/ topic/typicity (last visited Dec. 3, 2005). 
changes have aimed at producing wines of a different nature, at times meant for modern, foreign tastes.127 Either way, the result has been a break with traditional methods of production, despite GI protection. Differences of opinion between "traditional" and "modern" winemakers can be deeply entrenched and have even been known to carry acrimonious social effects, partly on the background of economic competition, partly as a genuine divisiveness of aesthetic philosophy; case in point is the Piemonte region of northern Italy, where the traditional/modern divide is sometimes referred to as the "Barolo Wars." 128

Market-induced changes in traditional methods of production can therefore occur working within the regulatory space of the GI/appellation legal system, which is ineffective in preventing such innovations. On the other hand, some modernization that significantly strays from traditional methods embodied in appellation rules cannot benefit from the GI. Indeed, market forces are sometimes strong enough to encourage producers to forego the GI they are legally entitled to in order to pursue new production methods. This happened in Tuscany, where innovators looking at international markets abandoned the prestigious Chianti Classico Denominazione d'Origine Controllata e Garantita ("DOCG"), preferring to introduce non-Tuscan grape varieties such as Cabernet Sauvignon into the blends that made up some of their best wines and to bottle them under the formally inferior Toscana Indicazione Geografica Tipica ("IGT"), and before the latter category's creation under the humiliating classification of Vino da Tavola ("VdT") (literally, table wine). These luxury wines soon became known as Super Tuscans and overtook the Chianti Classico wines in terms of international, high-end demand, but also entered lowend markets, all at the expense of traditional blends. This is an evolutionary model that has been replicated in various other

127 In particular, traditionalists decry the effect of the taste of a single palatethat of the influential American wine critic Robert J. Parker, on the development of regional wines. ECHIKSON, supra note 1, at 89; Suzanne Goldenberg, 'I Am the Most Powerful Person in the Wine World,' THE GuARdian, July 23, 2003, Food Section, at 8; see also MONDOVINO (Goatwork Films \& Films De La Croisade 2004) (providing Nossiter's stylized depiction of the role of powerful figures such as Parker and the winemaking consultant, Michel Rolland, in the design of the modern wine trade). Interested readers can visit the critic's website. Robert Parker Online, http:/ / www.erobertparker.com (last visited Dec. 2, 2005).

128 See, e.g., JOSEPH Bastianich \& DAVID LyNCH, Vino ITAliano: THE REGIONAL WINES OF ITALY 147-48 (2002). 
regions in Europe. With innovators working outside the appellation system, in these cases GIs have been unable to forestall the erosion of what may be regarded as one of the most basic traditions of wine production: the local cépage, or varietal composition of local wines.

The history of the Chianti Classico DOCG also reveals that market pressures may actually bring national GI regulators to amend the traditional production requirements set out in the appellation rules themselves, making a clean break between the GI and its underlying tradition. Chianti is perhaps the world's first legally defined GI, by virtue of a Decree by Grand Duke Cosimo III de' Medici from 1716.129 The father of modern Chianti, however, was the Baron Bettino Ricasoli, who in the 1850s defined a standard varietal blend for Chianti wine, composed mainly of the red grapes (Sangiovese and Canaiolo Nero), but also up to $30 \%$ white grapes (Malvasia and Trebbiano), the white varieties intended for freshness and accessibility in early drinking. This became the traditional composition of Chianti wine for more than a century. The Chianti region gained protected status by ministerial decree in 1932, and under legislation became a Denominazione d'Origine Controllata ("DOC") in 1967 which adopted the Ricasoli recipe, including the mandatory inclusion of a high minimum content of white varieties in the red wine as a binding condition for the use of the Chianti name.

Additionally, the use of white grapes in the red wine was being abused by winemakers to "stretch" or increase production quantities with little regard to quality. ${ }^{130}$ At the same time, the Super-Tuscan breakaways were threatening the Chianti reputation. In 1984, when Chianti as a whole and the Chianti Classico subregion were elevated to the more prestigious DOCG status, the new legislation significantly reduced the minimum content of white grapes in Chianti wines to only $2 \%$-a proportion so small that it is safe to say that it was kept simply in order to preserve a shadow trace of the Ricasoli tradition-and allowing the inclusion of non-local varieties up to $10 \%$ of the blend. The law was changed again in 1996, eliminating entirely the requirement of white variety inclusion, now rather subjecting it to a $6 \%$ maximum, and increasing the allowed proportion of foreign varieties to $15 \%$. 
Finally, under the current production code, as of the 2006 harvest, the inclusion of the indigenous white varieties will be prohibited if the wine is to be called Chianti Classico. ${ }^{131}$ Thus, market requirements - the achievement of higher quality that conforms to internationally accepted tastes and standards-and pressures, notably the abandonment of the DOCG system by many producers for their highest quality wines, have stood what was previously deemed a tradition on its head: a winemaking practice that was once a mandatory legal condition for GI status is now prohibited by the successor law. 132

Another manner in which different market pressures may detract from the integrity of cultures of production that are supposed to be protected by GIs relates to the ease with which appellation maps are drawn and redrawn. For example, the St. Joseph AOC was once "a single hillside,"133 "a snug local appellation centered on a handful of communities on the west bank of the northern Rhône," with a vineyard area of 245 hectares."134 In 1969 the AOC's permitted area of production was tripled, including much low quality land and causing a stampede of indiscriminate planting, ${ }^{135}$ leading one (American) expert to write that "nothing is sacred to these officials of the INAO"136 who

131 See Chianti Classico, http://www.chianticlassico.com/english/il-chianticlassico.htm (listing the requirements for a wine to be called Chianti Classico) (last visited Dec. 3, 2005).

132 Less drastic though significant changes in the traditional varietal composition of regional wines have occurred elsewhere within the regulatory space of GI definitions, due to economic factors relating to production. To name two: First, very few of the current wineries of the French Southern Rhone AOC of Chateauneuf du Pape practice the somewhat mythical traditional blend that includes no less than thirteen local varieties, as allowed by AOC rules. For many decades of the twentieth century, Chateauneuf du Pape wines relied mainly on a single variety (Grenache); this "tradition" has also been supplanted, as today most domaines use the three main varieties of the region (Grenache, Syrah and Mourvedre). JOHN LIVINGSTONE-LEARMONTH, THE WINES OF THE RHONE 174 (3d ed. 1992). Second, in the Northern Rhône AOC of Côte Rôtie, tradition called for blending a noticeable proportion of the aromatic white variety Viognier into the red Syrah-based wine. Id. at 8.

133 See LYNCH, supra note 99, at 178 ("Originally, Saint-Joseph referred to a single hillside between Mauves and Tournon which is now the property of the Chapoutier family. ").

134 See LIVINGSTONE-LEARMONTH, supra note 132, at 104 (showing the sharp increase in total area from 97 hectares in 1971 to 245 hectares in 1982).

135 See id. (explaining that the increased planting was hurting the St. Joseph's name).

136 Institut National des Appelations d'Origine ("INAO"), is the French 
continue to devalue these historic sites even though they were hired to protect them." 137 This was a change with implications for traditions of consumption (once St. Joseph's reputation declined) and of identity (expanding the "community". of winegrowers who may sell their wares under the St. Joseph GI, but eroding its quality); it should, however, be seen foremost as a shift in a culture of production, since it signaled an abandonment of the terroirdriven principles of winemaking. Or rather, one should say that it constituted a threat to these cultures, because in the early 1990s renewed local quality-consciousness (prompted, no doubt, also by difficulties in sales) launched an effort to redefine the St. Joseph territory, limiting its use to only worthy sites, ${ }^{138}$ evidently with growing success. ${ }^{139}$ Notably, in this case it was not the GI that saved the culture of production, but the producer's culture (and the decreasing value of the wines) that appeared to have saved the GI.

The same can also be said of the great classified estates of Bordeaux. They are all wine-making enterprises whose quality was ranked and classified according to their market prices in 1855. Subject to constant criticism, the 1855 classification has survived with very few changes. Yet as a prominent historiographer of the classification has noted, "[i]n theory, there is nothing to prevent a classed growth that consisted of, say, 25 hectares in 1855 from acquiring 100 hectares of neighboring vineyards that were classed lower in the hierarchy-or, for that matter, not classed at all." 140 Nevertheless, the quality rankings have been substantially preserved to this day. This can be attributed not only to the prescience of the original classifiers, but also to the care taken by successive proprietors to preserve the territory and quality to which the original ranking was granted.

governmental regulator of AOCs.

137 See LYNCH, supra note 99, at 179.

138 See LIVINGSTONE-LEARMONTH, supra note 132, at 104-106 (giving examples of how commercial success rather than quality became a driving factor in the late 1970s and 80s, and how this has changed in the 1990s).

139 See Todd M. Wernstrom, Saint-Joseph: Less Proves More in the Northern Rhône, THE WINE NEWS, Apr.-May 2004, available at http:// www.thewinenews.com/aprmay04/cover.asp (describing how the AOC redrew the area where St. Joseph's is grown to increase quality by removing those vineyards on the valley floor that had been included in an expansion of the appellation in the early 1970s).

140 MARKHAM, supra note 105, at 184. 
In sum, from the tested experiences of GIs in France and Italy (as well as in Spain), it is evident that market pressures are independently and markedly more influential than legal GI regulation with regard to patterns and practices of production, at least as far as culture is concerned. Where the market demands change, change is enacted, regardless of GI rules; where the market encourages constancy, constancy in GIs is achieved, whether directly or indirectly.

\subsection{The Culture of Consumption: Markets Change Cultures of Discriminating Consumption Despite GIs}

A second proposition regarding the ineffectiveness of GIs as agents of cultural preservation is that markets change cultures of consumption relating to GI-protected products, even those that are based on traditions of discrimination (in taste, not in trade). Not only are they not enough to conserve cultures of discrimination, GIs-or at least the way that they are legally defined and managed - may even contribute to these changes.

This is exemplified by recent trends in the British wine market, vis-à-vis Old World and New World wines. As has been discussed already, England is an example of a consumer market with established traditions of non-protectionist geographical discrimination in terms of tastes and preferences for food and wine. ${ }^{141}$ Not surprisingly, France has historically been Britain's main supplier of wine; and Britain has always been an important export market for French wine. Yet sales figures for the year 2000 shockingly revealed that Australian wine exports had, by value, surpassed French wine exports for the first time ever, ${ }^{142}$ a shift that reflected trends in other world markets as well,143 and that has

141 See discussion supra Section 3.3.

142 It has been claimed that by volume, France's exports to Britain exceeds those from Australia. However, this only indicates that on average, the British are willing to pay more for a bottle of Australian than French wine. See generally Jim Budd, CAP 2010: France Faces the Competition, WINE Bus. MONTHLY, Dec. 3, 2002, available at http://www.winebusiness.com/html/PrinterVersion.cfm?datald= 20791; France's Wine Market Losing Global Market Share to New World Producers, FOOD \& DRINK WKLY., Aug. 20, 2001, available at http:// www.findarticles.com/p/articles/mi_m0EUY/is_33_7/ai_77575053.

143 Reportedly, the share of French exports in the United States wine market has dropped from over thirty-three percent in the 1990s to fifteen percent. See Gordon T. Anderson, Can Anything Save French Wine?, CNN MONEY, Aug. 23, 2004, http://money.cnn.com/2004/08/19/pf/goodlife/french_wine/ (describing the recent hits that the French wine industry has suffered). 


\section{continued since.}

The severity of this finding for the French wine industry must be understood in the context of more general market trends. Wine consumption in France has decreased significantly in the postWorld War II era, making export markets more important than they have been in the past. Wine consumption in non-traditional markets has grown, but so has the quantity and quality of wine products from "New World" sources. In fact, a combination of factors, not least French overproduction of low quality wine, has led to a global wine glut. The share of exports in world wine consumption is growing, although in most wine-producing countries, the majority of produce is still consumed locally.144 In short, the loss of ground in a traditionally faithful export market served as a frightening "wake-up call" for the complacent French wine industry, leading the French Department of Agriculture to commission a report on the need for reform. ${ }^{145}$ A key issue subsequently identified as requiring rethinking is the regulation of French AOCs and wine-labeling for export. In the debate that has ensued, proposals include scrapping the system, liberalizing it, 146 adding new high quality categories, ${ }^{147}$ or various variations on and

144 See generally Budd, supra note 142; Brian Croser, Winemaker, Petaluma Vineyards, Annual WSET Lecture 2004: Brand or Authenticity? (Feb. 23, 2004) available at http://www.wset.co.uk/docs/File35-2004AnnualLecture.doc (explaining the impact that the emerging Australian wine industry has on the global wine market); Andrew Inkpen \& Rod Phillips, The Wine Industry, http://www.thunderbird.edu/pdf/about_us/case_series/a09030026.pdf (last visited Dec. 3, 2005) (detailing the history of the wine industry and its present-day state); Nicholas Le Quesne, Vintage Advantage, TimE EuroPE, Aug. 12, 2002, available at http://www.time.com/time/europe/magazine/article/0,13005 901020819336011,00.html (describing the French wine industry's response to global upstarts).

145 See Jacques Berthomeau, Comment mieux positionner les vins français sur les marchés d'exportation? [How Could French Wine Be Better Positioned in the Export Market?], (2001), http://www.agriculture.gouv.fr/spip/IMG/pdf/

rappberthomeau-0.pdf (detailing the state of the French wine industry).

146 See Interview by Alain Bloeykens with Jacques Berthomeau, Consultant, French Ministry of Agriculture, The Money Flow Will Be Cut Off Without Hesitation, available at http:/ / www.underthecork.be/en/community/archief/may_02_

art1.html (arguing that drastic measures must be taken to save the French wine industry).

147 See Jon Henley, French Move the Goalposts in an Attempt to Halt Plunge in Wine Sales, THE GUARDIAN, May 1,2004 , at 3 , available at http://www.guardian.co.uk/france/story/0,11882,1207403,00.html (discussing the new technologies and methods the French have applied to their winemaking to halt sliding sales). 
combinations of these ideas. Thus, the future of French AOC regulation may hold many changes in mandatory methods of production within the GI system-which may yet emerge as another example of the ineffectiveness of GIs as protectors of the culture of production.

Concerned as we are in this section with traditions of consumption, however, let us focus on the British consumer market itself, not on its implications for French production. The gradual shift from French dominance to Australian (as well as North and South American) wine preference in Britain is likely the result of many combined market factors: the comparative advantage of Australia and other New World countries in the production of low-cost, successfully marketed, stereotypically gutsy wines full of ripe and vivid fruit flavors that provide easy drinking immediately upon release presents consumers with higher quality in lower price brackets and evidently panders to contemporary British consumer preferences. What is important for our purposes, however, is that underlying this market-induced change in consumption patterns is what may be perceived as a near-paradigmatic shift in consumption culture: the demise of a tradition of geographically discriminating consumption and the emergence (or rather, reinforcement) of a culture of consumption based on commercial branding. One of the distinctions between Old World and New World wine products is the system and style of their labeling and the degree of prominence accorded to their geographical designations. In addition to the name of the producer or merchant, French wines list the name of the GI: an $\mathrm{AOC}$ or a lesser denomination. In France alone there exist in excess of 500 such indications, sometimes distinguishing small, adjacent plots with vastly different historical or current quality ratings and market prices. Furthermore, quality French wine labels (with the exception of those from Alsace) are prohibited from displaying the name of the grape variety from which the wine is made. In contrast, Australian wines, like American and other New World wine labels, usually list the producer, a brand and the name of the grape variety involved-even when it is a blend. ${ }^{148}$ There may also be a GI, but for most wines, certainly low-tier ones

148 The normal rule in New World jurisdictions is that a wine may be labeled as a mono-varietal wine (e.g., Chardonnay or Cabernet Sauvignon) if a single variety constitutes $85 \%$ or more of the volume. Below that figure, the wine must be labeled as a blend (e.g., Cabernet Sauvignon-Merlot). 
intended for mass-marketing, these will be very general. California or South-East Australia wines, for example, have designations that refer to territories with a size comparable to that of all of France.

In theory, the GI-intensive French system should therefore enjoy a comparative advantage in promoting its wines in a market with consumer traditions of geographical discrimination. Yet the experience in Britain shows that GIs have failed to prevent the erosion-or rather, the transformation-of consumer culture. It has simply become too difficult for the casual, nonexpert consumer to maintain a working knowledge of French appellations and their association with the kinds of wine he or she wants most. Examples of difficulties abound. If the consumer wants a Chardonnay, should she order a Pouilly-Fuisse or a Pouilly-Fume? If he likes Bourgogne, should he consider a Bourgogne-Passe-tout-grains? Is a Montrachet really so much better than a Puligny-Montrachet? If one likes Syrah, should one buy a Côtes du Rhône or a Cote Rôtie? Is a Muscadet des Coteaux de la Loire any different from a Muscadet Côtes de Grand Lieu? Similar problems of the density and intricacy of GIs surface in other "Old World" countries such as Italy, in which the palette of legally defined and protected GIs has grown and spread to new DOCs in every region, including many that will sound obscure to even the reasonably knowledgeable wine buff (e.g., Tuscany, which has Montecucco, Monteregio di Massa Maritima, Montescudaio, Candia dei Colli Apuani, Capalbio, Orcia, Sant'antimo on top of the better-known DOCs and DOCGs, ${ }^{149}$ and Germany, which has a particularly elaborate wine law and labeling system). ${ }^{150}$

In comparison, it has become much easier for the general consumer to make informed assumptions on the character of a potential wine purchase on the basis of passing experience with a few grape varieties from a handful of countries and producers, not regions: "'Americans walk into a store and ask for a Chardonnay or a Cabernet .... They don't come in and start rattling off the

149 Full listings of Italian wine Indicazione Geografica Tipica ("IGTs"), Denominazione d'Origine Controllata ("DOCs") and Denominazione d'Origine Controllata e Garantita ("DOCGs") are available. E.g., BASTIANICH \& LYNCH, supra note 128 , at 400 .

150 See STEPHEN BROOK, THE WINES OF GERMANY 16-31 (2003) (detailing the wine laws of Germany and the problems encountered in reforming the vineyard classification system). 
names of this or that obscure chateau."'151 The slipping sales of French wine in Britain indicate that the British consumer has become more "American" in this respect. Yet this cultural shift is not exclusively or even necessarily the outcome of aggressive globalization or Americanization. In fact, it is to some extent the result of the overambitious GI protection programs pursued in the legal systems of continental European countries for wine products intended for export. Quite simply, the proliferation of GIs, which in GI justificatory theory should lead to full information and to better purchasing decisions, has led to information overload that considerably obscures the consumer's view of her purchasing options and decisions. Absurdly, it might be said that free trade is at fault even here: If not for liberalization of trade, the wines of the most incomprehensible AOCs would simply not be available in foreign, "barbarian"152 countries, leaving consumption up to the local French market.

In any event, in the field of traditions of consumption, we again see that GIs cannot withstand the cultural influence of market forces. It is not GIs that uphold culture, but rather culture that upholds GIs. ${ }^{153}$

151 Anderson, supra note 143 (quoting a wine merchant).

152 A term used in the Berthomeau Report, supra note 145 , at 81 .

153 At least two plausible objections could be raised in relation to this admittedly stylized depiction of the changes in the British wine market. First, it is clear that the class-minded British society was not always, and never entirely, a "geographically discriminating" consumership, and so the shift is not as dramatic as it would appear. See Angela Tregear, From Stilton to Vimto: Using Food History to Re-Think Typical Products in Rural Development, 43 SociologiCA RuRALIS 91 (2003) (analyzing in a highly nuanced, intelligent, and historically sensitive way the evolution of British consumption patterns in the pre-industrial, industrial, and post-industrial eras, while highlighting the influence of local raw materials and inherited, traditional production methods on food products). Building on Tregear, geographical taste in the pre-industrial era was a localized aspect of the close proximity of production and consumption (although it should be assumed that with regard to imports it applied mainly to nobility). Ever since, geographical discrimination has been restricted to the affluent classes and social elites, in the industrial era as a taste for specialty items, and in the post-industrial era as a reflection of nostalgia for rural roots and interest in "exotica." Therefore, it is possible that wealthy wine consumers have managed to overcome the complexities of ongoing geographical knowledge accumulation posed by the proliferation of GIs (increasing the gap between cognoscenti and nongeographically-minded consumers). Alternatively, they have weathered the storm by standing by the most time-tested appellations. Second, a distinction should be drawn between "super premium" wines that command high prices and may benefit from prestigious GIs at the proverbial "Grand Cru" level and lowpriced market-leading brands that need to sell in the less geographically-inclined 


\subsection{The Culture of Identity: The Market for GIs Invents Traditions, Dilutes Culture, and Distorts Identity}

A third proposition regarding the ineffectiveness of GIs as legal guardians of culture relates to their uncertain and potentially distortive effect on local identity. Much as some unique GIs do embody local cultural idiosyncrasies, reflecting a deeply inbred relationship between society and a uniquely local food and wine products, from a critical perspective many, and perhaps most of them, in fact represent legally "invented traditions" 154 and "imagined communities." 155 Even the most technically original, culturally-charged GI of all, Champagne, was legally established for primarily economic purposes: local identity and French nationalist symbolism served as rallying cries, an embellishment of reality for the purposes of a political campaign devised and pursued to ensure market protection. ${ }^{156}$

consumer market. For a discussion of the imperatives of such distinctions in modern wine markets, see Kym Anderson et al., Globalisation and the World's Wine Markets: An Overview, 26 WORLD ECON. 659, 661-69 (2003). The cumulative effect of these two precisions might suggest that there has not been a change in the importance of geographical discrimination. However, the increase in the average price commanded by Australian wines in relation to French wines suggests that this is not the case, and that a shift has occurred even in the more affluent-and traditionally geographically discriminating - classes of English society.

154 According to Eric Hobsbawm:

[Invented traditions are] "traditions" actually invented, constructed and formally instituted and those emerging in a less easily traceable manner within a brief and dateable period - a matter of a few years perhaps....

"Invented tradition" is taken to mean a set of practices, normally governed by overtly or tacitly accepted rules and of a ritual or symbolic nature, which seek to inculcate certain values and norms of behaviour by repetition, which automatically implies continuity with the past .... However, insofar as there is such reference to a historic past, the peculiarity of "invented" traditions is that the continuity with it is largely factitious.

Eric Hobsbawm, Introduction: Inventing Traditions, in THE INVENTION OF TRADITION 1-2 (Eric Hobsbawm and Terence Ranger eds., 1983).

155 This is a phrase coined by Benedict Anderson in the context of nationalism. BENEDICT ANDERSON, IMAGINED COMMUNITIES: REFLECTIONS ON THE ORIGINS AND SPREAD OF NATIONALISM 5-7 (rev. ed., 1991).

156 See Guy, supra note 8, at 163-73 (describing the marketing of wines that appealed to nationalist sentiment). More generally, what may be understood as the role of fantasy in the association of French national identity with wine is presented by the same author in Kolleen M. Guy, Rituals of Pleasure in the Land of Treasures: Wine Consumption and the Making of French Identity in the Late Nineteenth Century, in FOOD NATIONS: SELLING TASTE IN CONSUMER SOCIETIES, supra note 7, at 
As the use of GIs spread throughout Europe, later under the canopy of international treaties and ultimately within the WTO, one of the phenomena that emerged may be described as a market for GIs, with both private and public choice aspects. On the private side, it was assumed that the consumer market assigned higher value to GI-designated products. The need for GI-have-nots to level the playing field with the GI-haves, resulted in a demand by producers for GIs - either as entirely new GIs, as breakaways from established GIs, or as GIs to be promoted in the hierarchy of GIs. On the public side, government regulators became suppliers of legally protected GIs. The pattern established in Champagne became the standard, as regional groups of producers, together with labor unions and local municipal governments, lobbied national agencies for GI recognition. Part of this lobbying process required arguments regarding the quality and singularity of the product (usually satisfied by a relatively simple demonstration of terroir), but GIs, as rights, have to be given to somebody-not a private entity, but a community, and one with a tradition. Thus, communities had to crystallize around the common interest of attaining GI status for local products, both for simple collective action needs and to satisfy the reputational and legal criteria for GI acquisition. This process proved self-perpetuating. Governments found it difficult and indeed politically inexpedient to refuse GI status to one region after having granted it to another, so that ultimately, the wine AOCs in France and DOCs in Italy might be said to cover virtually every viticultural area that could be associated with a locality. These market dynamics of GI acquisition have resulted in a proliferation of wine appellations in the Old World and, increasingly, in New World producing countries.

It has already been noted how the proliferation of GIs has

34. Much as Champagne has become perhaps the most belligerent of GIs, it has been argued that the term has been internationally used as a generic term for sparkling wine for decades. In any event, as this Article was completed, the United States and the European Union reportedly reached an agreement according to which the United States, agreed inter alia to prevent the use of "semigeneric" names, including Chamapagne, with respect to U.S. wines (without recognizing them as GIs), subject to "grandfather rights" for brands using these terms at the time of the agreement. Office of the United States Trade Representative, Trade Facts, United States-European Communities Agreement on Trade in Wine, Sept. 15, 2005, http:/ / www.ustr.gov/assets/Document_Library/ Fact_Sheets/2005/asset_upload_file611_7970.pdf. 
contributed to consumer confusion by eroding the consumer culture of geographical discrimination. ${ }^{157}$ Additionally, the GI explosion has likely contributed to a general devaluation of GIs and GI-led products, thereby reducing the economic capacity of GIs to protect tradition. An advantage enjoyed by many, if not all, is not generally an advantage anymore. Furthermore, the abundance of GIs hints that, in practice, satisfying a low threshold of regional or local distinctiveness is sufficient for bestowal of GI status, including only vague references to local traditional practices - a functional dilution of the cultural rationale. In many cases, new GIs are indeed attempts to establish instant reputations through invented traditions that building a novel culture through self-reference to the distant or at least irrelevant past. Some of the more recent Tuscan DOCs listed above are cases in point, 158 as are others in several emerging regions of Italy, inasmuch as they are in fact areas that may (or may not) have had some reputation for distinctive wines more than a century ago (at best) or in the time of the Etruscans (at worst), but for generations this aspect of the land and the people has been defunct. ${ }^{159}$ Moreover, these regions have been invigorated by some local efforts, bolstered by capital and enterprise flowing from other established areas. For example, according to popular knowledge, the coastal Tuscan Morellino di

157 See discussion supra Section 4.3.

158 See supra text accompanying notes 130-31.

159 The invention or re-invention of tradition can appear in commercial contexts even when there is no GI involved. For example, the relatively new Israeli wine industry has some wineries that stress the historic roots of wine in the holy land, by depicting ancient grape presses or ruins on their labels. See Ella Valley Vineyards: About Us, http://www.ellavalley.com (last visited Dec. 6, 2005) ("Archaeological findings such as ancient presses and vineyards attest to Ella Valley's importance as a winemaking region thousands of years back, in the biblical Land of Israel."). In one very new project in the Negev desert, vines have been planted along terraces that are designated as archaeological relics from the Nabbatean (Byzantine) period. See Desert Wine, SOURCE ISRAEL ONLINE, http:/ / www.thesourceisrael.com/issue3/intimate.shtml (last visited Dec. 6, 2005) ("Well-versed in the agricultural successes of the Nabateans 1000 years earlier at Avdat (a few kilometers from Kibbutz Sde Boker), Ben Gurion envisioned modern vineyards that would make the desert bloom."). In another development, one sees the emergence of "borrowed traditions," as local municipalities produce maps of wine routes, and publicity material hails the Galilee or Judean Hills as an Israeli Tuscany or Provence. See Tour Yoav, http://www.touryoav.org.il (Hebrew website). Indeed, in the absence of formal GIs for Israeli wines, one of the best and longest established Israeli wineries labels its wines as "Grand Vin de Haut-Judée," emulating and informally assimilating the regional traditions of France. Domaine du Castel, http://www.castel.co.il. 
Scansano DOC, established in 1978, can boast some positive references to its wines in the Middle Ages, and as late as 1848.160 When the Scansano wine was granted a protected GI it had little to offer, however, in the way of quality. A handful of local wineries made good efforts, but more importantly, some of the big players in the central Tuscan wine industry recognized commercial potential in the area, bought land, planted new vines, and built wineries.

In short, in this and other cases, a DOC whose cultural foundation had little to do with present local culture reinvented itself by recalling its distant past in order to be more commercially relevant in the future. The "award" of a GI provided an incentive to invent tradition; the effects on the real tissue of local culture, however, are unknown.

Perhaps most importantly-though most difficult to substantiate on a sound anthro-sociological basis without considerable research-the invented traditions themselves, pursued for commercial purposes within the market for GIs, may ultimately emphasize the more marketable aspects of local wine and food culture, even invented ones, neglecting other less commercially attractive aspects. Again, Champagne is somehow instructive in this regard, because, until the mid-nineteenth century, local culture was more related to still wines, not Méthode Champenoise sparkling wines. Economic expediency produced the push for early GI protection that required an emphasis on the local and French ethos of sparkling wine. This is similar to the complex effects of tourism on communities. 161 In order to attract tourism, communities must emphasize what makes them special, and of course, agreeable from an external, market perspective, not in terms of their own self-determination of identity and aspiration. A community, real or imagined, that, for economic purposes, is interested in gaining GI status, will clearly need to emphasize those aspects of its local food or wine culture that are marketable for this purpose. As in the example of Morellino di Scansano DOC,

160 See Italian Trade Commission http://www.italianmade.com/ wines/DOC10213.cfm (noting the long-standing excellent reputation of Scansano wine).

161 See generally Michel Picard \& Jean Michaud, Présentation-Tourisme et sociétés locales [Introduction-Tourism and Local Societies], ANTHROPOLOGIE ET SOCIÉTÉS, 2001, at 5-13, available at http://www.erudit.org/revue/ as/2001/v25/n2/000230ar.pdf (describing the effects of tourism on local culture and society). 
above, the cost, in terms of lost, un-invented tradition, is forever unknown.

\section{DOLCI: THE FUTURE OF CULTURAL PROTECTION IN WTO LAW}

\subsection{Implications for the WTO GI Debate and Beyond}

This Article could have ended here, with a simple, neat conclusion: GIs, as legal mechanisms and quasi-intellectual property rights, evidently do not have the independent capacity to protect local cultures of production, consumption or identity, or to prevent the erosion of cultural diversity. Market forces inevitably induce changes in local production methods and consumption preferences, in spite of the GIs that should, in theory, play a role in preserving them, and the proliferation of GIs has itself diluted the claims of special reputation, typicity, and cultural identity of GIendowed locales.

For negotiators at the WTO, the consequent recommendation would, therefore, be to abandon any romantic rhetoric of cultural protection in the debate over expansion of article 23 of TRIPS "additional protection," 162 and to recognize GIs and treat them exclusively as what they are: legal tools for granting commercial advantages to certain products, sectors and regions. GIs are instruments of trade policy, like tariffs, subsidies or serviceprovider regulations. GIs should, therefore, be negotiated and maintained as such: free of all overweight "cultural" baggage such as tariff concessions, subject only to reciprocal commitments and nondiscrimination obligations of WTO members relating to their respective GIs. Furthermore, since culture cannot of itself justify any GI protection, it should not be used as a justifying measure for selecting some GIs as eligible for "additional protection," or for preferring some GI-able products over others. There may (or may not) be plausible reasons to provide only regular protection to some GIs and "additional protection" to others, but cultural diversity is not among them. There seem to be good reasons to scrap "additional protection" entirely, but that seems politically unlikely. Given that the current legal situation clearly discriminates against developing countries-because most wine and spirits GIs are from developed countries-regardless of

162 See supra text accompanying notes 20-21 (referring to "protection granted even when there is no risk of misleading consumers or unfair competition"). 
cultural justifications, article 23 of TRIPS "additional protection" should be extended to all GIs, of all members (indeed, the European Union will be the greatest single beneficiary from extension, but the viability of GIs of developing countries will be much greater than at present).

Moreover, we have endeavored to take "trade and culture" seriously, beyond the limited test case of GIs. What emerges more generally, then, from the case study of cultural protection through GIs is the following striking image: An international legal mechanism with trade restrictive effects, widely believed to have a positive effect on preserving cultural diversity, and with a plausible underlying theory of cultural protection to boot, which in practice, simply does no such thing. Cynics or uncompromising neo-liberal trade theorists might be quick to interpret this as proof that trade restrictions, in general, cannot contribute to cultural diversity and that all trade-related claims calling for cultural protection are merely disguised calls for economic protectionism. While this may be true in some or even many cases, I would instead suggest some less simplified observations, not rejecting the idea of cultural protection through trade restrictions entirely, but rather qualifying the ways in which proposed legal methods for cultural protection are to be assessed and applied.

These thoughts, laid out hereunder (in an initial way, worthy of further contemplation and discussion), relate to:

- the desirability of specific, sui generis cultural protection from trade liberalization;

- the viability, applicability, and mechanics of a general cultural exception in international trade law; and

- some of the problems associated with the development of a separate, UNESCO-based cultural protection regime that would impact upon rights and obligations in the WTO.

\subsection{Thinking About Sui Generis Cultural Protection}

Insofar as GIs represent an approach to cultural protection based upon sui generis legal measures in international trade law, it is apparent that the real cultural effects of such measures must be analyzed with care, if not caution (which is not always to say, with 
skepticism).

Tailor-cut, sui generis, case-by-case methods have the advantage of avoiding unnecessarily restrictive generalized exceptions to trade rules (an advantage significantly eroded if specialized measures are established in addition to general exceptions). Nevertheless, sui generis measures have the potential to expand trade-protectionism beyond what is necessary-or effective-for cultural protection even within their own targeted scope. Specifically, agreed upon trade-restrictive measures and mechanisms that are based upon a theory of cultural protection should therefore be defined in the strictest possible terms, on the basis of sound quantitative and qualitative research, adhering in practice and effect to their cultural rationale. This is not only necessary to mitigate the welfare-reducing economic effects of such measures, but also to maintain their coherence and, indeed, legitimacy as cultural protection mechanisms. "Culture" should not be allowed to become a euphemistic code word for protectionism.

It is probably too late to entirely undo the idea of GI protection on the mere argument that it is not conducive to cultural protection. However, proposals for similar sui generis trade or intellectual property disciplines that refer to a cultural protection justification ${ }^{163}$ should be subjected to rigorous cultural - not only legal and economic - analysis, in order to discern their real effects on both trade and culture. The GI experience suggests that it is not enough to demonstrate how free trade may harm cultural diversity. Of greater importance is substantiation that the sui generis measure can, in fact, prevent this harm in practice. Since such proof may be difficult or, indeed, impossible to procure before the measures in question are imposed, it would appear advisable for WTO members agreeing on new specialized measures aimed at cultural protection to define a test-run or sunset review period for the measure. At the end of this period, not only could the measure's trade impact be evaluated, but a "cultural impact assessment" could be conducted, relating to predetermined criteria. This could be conducted by recognized experts, with UNESCO involvement. If these criteria are not met, the international legal measure should be abolished or modified

163 Traditional knowledge may be deemed one of these cultural protection justifications; indeed, GIs are sometimes referred to as a tool for protecting traditional knowledge. See supra note 3. 
accordingly - not because it is trade-restrictive, but because it does not promote cultural protection.

In addition, members-and in particular developing countries - who are considering adopting GIs as a suitable vehicle for the protection of rights in traditional knowledge, or who would like to see stronger specialized rules for cultural protection in the WTO and elsewhere, should be aware that although such modalities may increase the commercial value of existing cultural goods and services, their effect on cultural preservation and diversity is indeterminate at best. This is because GI protected traditions might nevertheless in the future succumb to economic pressures and international consumer preferences. GIs and other trade-related measures must be augmented by more comprehensive flanking policies and competent regulation if cultural diversity is to be preserved.

\subsection{Thinking About a General GATT/GATS Cultural Exception}

Our examination of the questionable practical ability of GIs to fulfill the role of cultural guardian raises several questions and suggestions relating to the viability, applicability and mechanics of a general cultural exception in international trade law. To be sure, the existing general exceptions in Article XX of GATT and Article XIV of GATS cannot be said to expressly establish a comprehensive exception for cultural policies, but some cultural legislation may be covered. The term "public morals" in Article XX(a) of GATT/ Article XIV of GATS has recently been interpreted as denoting "standards of right and wrong conduct maintained by or on behalf of a community or nation,"164 the content of which "for [WTO] members can vary in time and space, depending upon a range of factors, including prevailing social, cultural, ethical and religious values." 165 It is not difficult to see how this exception, so defined, could apply to preventive policies (such as age limits for legal alcohol consumption, legal regulation of the sale and shipping of alcoholic beverages, and so on) that relate not only to public order but also to cultural mores, or to restrictions on the sale and importation of foodstuffs that are culturally offensive in the

164 See US-Gambling II, supra note 2, If 296 (affirming, implicitly, the definition of "public morals" in Panel Report, United States - Measures Affecting the Cross-Border Supply of Gambling and Betting Services, If 6.487, WT/DS285/R (Nov. 10, 2004) [hereinafter US - Gambling I]).

165 US - Gambling I, supra note 164, ๆ 6.461. 
importing state, for such reasons as religion (e.g., beef products to a Hindu region, alcohol to a Muslim state, non-kosher foods to Israel). ${ }^{166}$ It is, however, much more difficult to envision this language applying to import restrictions based on a positive cultural policy aimed at the preservation of a certain local craft or trade (such as artisanal wine- or cheese-making), if only because such a policy would not regularly relate to "standards of right and wrong." Indeed, to include all cultural policies in the "public morals" exception would be tantamount to expanding its scope to include practically any legally regulated field, i.e., reductio ad absurdum. (In the field of services, at least, this would be inconsistent with the strict requirement in footnote 5 of Article XIV(a) of GATS, according to which "the public order exception may be invoked only where a genuine and sufficiently serious threat is posed to one of the fundamental interests of society.")

For the same reasons, it would also be an exaggeration to allow domestic GI legislation (as an example of ostensibly cultural policy) to benefit from the public morals exception, had GIs not been specifically permitted and regulated by TRIPS as sui generis measures.

Thus, while culture may at times inform local morality, surely not all cultural issues are related to "public morals."

Similarly, the Article XX(f) of GATT exception is limited to the protection of "national treasures of artistic, historical or archeological value." This should properly be read as relating to specific, physical artifacts of national importance, directed mainly to justify export rather than import restrictions. Champagne may sincerely be regarded by the French as a national treasure, ${ }^{167}$ as may other champion food and wine products, but it would be an abuse of this exception to interpret it as permitting trade restrictions for their preservation. The same logic would apply to other cultural policies. For example, each nation's language may be a national treasure of sorts, but Article XX(f) of GATT cannot be reasonably stretched to justify trade-restrictive measures based on language policies.

Moreover, WTO members could conceivably expand the meanings of these exceptions to include a broader range of cultural policies (through treaty amendment or "authoritative

166 Of course such legislation would also have to satisfy all other elements of Article XX(a) of GATT / Article XIV(a) of GATS in order to be WTO consistent.

167 See supra note 117. 
interpretation" under article X or article IX(2) of the WTO Agreement, respectively). ${ }^{168}$ Regardless of the specific wording of such an expanded exception relating to cultural protection, 169 and whether through amendment or interpretation (judicial or quasilegislative), the question would then arise regarding the conditions to be met by a trade-restrictive measure in order to benefit from the cultural exception.

Drawing from Article XX(a) of GATT/Article XIV(a) of GATS case law and otherwise analogous GATT Article XX jurisprudence, two cumulative conditions specifically addressed at "cultural protection" seem likely (in addition to the other conditions of the respective chapeaux of Article XX of GATT/Article XIV of GATS). First, the trade-restrictive measure must be within the scope of the "cultural protection" exception ${ }^{170}$; second, the measure must be "necessary" for the protection of local culture and cultural diversity. ${ }^{171}$

In this regard the present Article's conclusions regarding the problematic actual effect of GIs on the preservation of local tradition and cultural diversity, may cast a critical shadow on current WTO jurisprudence as applied to cultural issues. This is because panels and the Appellate Body are often receptive to the non-trade theories underlying trade-restrictive measures insofar as finding the measures to be within the scope of an exception is concerned (the first condition). They are more critical at the later

168 See TOMER BROUdE, INTERNATIONAL GOVERNANCE IN THE WTO: JUdiCIAL BOUNDARIES AND POLITICAL CAPITULATION 213-17 (2004) (discussing the legislative capacities of the WTO General Council).

169 The language of the various sub-provisions of Article XX of GATT, and Article XIV of GATS, is not consistent, including the most frequently used and applied "necessary to" (e.g., sub-Articles XX(a), (b), (d) and also (i) GATT), "relating to," "imposed for," "undertaken in pursuance," and "essential to"). Different language has led to different interpretations, reflecting a varying "required nexus" or "degree of connection" between the measure and the protected interest. See US - Gambling II, supra note 2 II 292 (discussing the "twotiered analysis" under Article XIV of GATS). In the present (hypothetical) analysis, we assume that the wording "necessary to" would be applied to a general cultural exception, if applied, but this would naturally be one of the issues subject to member negotiations.

170 E.g., US - Gambling I, supra note 164, I 6.449 (relying on prior Appellate Body Reports, including Korea-Various Measures on Beef, WT/DS161/AB/R, WT/DS169/AB/R (Dec. 11, 2001) [hereinafter Korea-Beef], to illustrate the twotiered analysis).

171 Cf. Korea-Beef, supra note 171, If 161 (discussing possible interpretations of the word "necessary" and linking the definition to "indispensable"). 
analytical stages relating to the "necessity" of the challenged measures (the second condition), and the overarching requirement of the measures' conformity with the Article XX of GATT / Article XIV of GATS chapeaux. In the US-Gambling case, for example, the panel adopted a very lax test for the satisfaction of the first condition, regarding the question of the measures' inclusion within the scope of "public morals." It only briefly examined the legislative history of the challenged measures, and concluded that the record shows that their rationale was one aimed at the protection of public morals. ${ }^{172}$ The requirement that the measure be "within the scope" of an exception has in practice been transposed into a requirement that the measure be "designed to" achieve the goal of the exception. ${ }^{173}$ In a cultural exception, the measure would therefore be required, for example, to "be designed to protect local culture."

This may be (and with regard to other protected interests, has in practice been) constructed as a mainly subjective test (building principally on the declared intent of the legislator), ignoring the possibility of ulterior, multiple, or misguided motives for legislation. As a legal test, it does not objectively examine the actual effectiveness of the challenged measure in achieving its alleged aims. On appeal, the Appellate Body in US - Gambling also disposed of this issue very briefly, limiting itself to the grounds of appeal which did not include a challenge to the inclusion of the measures in question within the scope of the "public morals" exception. ${ }^{174}$ It was "quick to justify"175 the challenged legislation

172 US--Gambling I, supra note 164, ๆ $6.479-6.487$ (in particular $\|$ ๆ 6.4866.487). The panel referred to a 1961 Report to the House of Representatives and to a statement by the late Robert F. Kennedy, but did not require positive evidence regarding the effectiveness of the legislation in meeting its declared purposes in the four decades that had passed. The panel concluded on this point that it was satisfied that "various arms of the government of the United States consider these Acts were adopted to address concerns such as those pertaining to money laundering, organized crime, fraud, underage gambling and pathological gambling," that fall within the scope of "public morals" and/or "public order" within the meaning of GATS Article XIV(a).

173 Id. ๆ 6.487.

174 The Appellate Body seemed understatedly critical of the absence of this claim on appeal. See US - Gambling II, supra note 2, I 297 ("Antigua contests this finding on a rather limited ground ....").

175 Joost Pauwelyn, ASIL Insight: WTO Softens Earlier Condemnation of U.S. Ban on Internet Gambling, but Confirms Broad Reach into Sensitive Domestic Regulation, ASIL INSIGHTS, Apr. 12, 2005, http://www.asil.org/insights/2005/ 04/insights050412.html. 
as conducive to the substantive purpose of the "public morals" exception. In general, WTO adjudicators appear to consider it more legitimacy-enhancing (and consistent with the requirement that their rulings not "add to or diminish the rights and obligations of the WTO agreements ${ }^{176^{\prime \prime}}$ ) to embrace the non-trade considerations at stake, and grant national authorities considerable leeway in their delimitation, while retaining the authority to strike the contested national measures down because they are overly trade-restrictive, given the existence of alternatives. In issues relating to cultural concerns that reflect particularly sensitive national sentiments, one can only imagine that panels and the Appellate Body will be at least as permissive in accepting measures as "within the scope" of a cultural exception.

Regarding the second condition, the US-Gambling panel followed the established relevant jurisprudence (particularly Korea-Beef) $)^{177}$ whereby the "necessary to" (or "necessity") test means significantly more than "making a contribution to" the protected interest, much closer to "indispensable." Consequently, and in keeping with a large mass of prior jurisprudence, the Appellate Body focused its review of this condition on an examination of the existence of viable, less trade-restrictive, substitutes for the challenged measure (a comparative, "indispensability" test), and not on the actual efficacy of the challenged measure (an absolute, objective "effectiveness" test). To be sure, one constituent element of the second, "necessity" test, is the extent to which the challenged measures "contribute to the realization of the ends respectively pursued" by them, 178 but in practice this element receives scant attention in cases where the actual effect of a measure on a protected interest is difficult to measure. Thus, in US-Gambling the panel (as upheld by the Appellate Body) simply concluded that since the challenged measures prohibit a form of services supply, "they must contribute, at least to some extent" to addressing the relevant

176 Understanding on Rules and Procedures Governing the Settlement of Disputes, Apr. 15, 1994, Marrakesh Agreement Establishing the World Trade Organization, Annex 2, Legal Instruments-Results of the Uruguay Round, 33 I.L.M. 1125, art. 3.2 (1994) [hereinafter DSU].

177 Korea-Beef, supra note 171, \ 161.

178 US-Gambling I, supra note 164, I 6.488. The other two constituent elements are the importance of the protected interest(s) and the trade impact of the measures. Id. 
concerns. ${ }^{179}$

This echoes the general assumption that trade restrictions can protect cultural values, consonant with the analysis in Section 3 supra-an assumption and analysis shown to be incorrect in practice, in the GI context, in the subsequent Section 4.

In other words, the panel and the Appellate Body in USGambling, in practice, accepted the protective "public morals" theory underlying the measures in question with little questioning, and, on its basis, assumed that the trade restriction established by them must have a protective effect. They then proceeded to examine the extent of protection on a comparative rather than absolute basis, mainly alluding to the availability of alternatives. Thus, at no point did the panel or Appellate Body critically examine the fundamental contention that the restrictive legislation had any measurable positive effect on the safeguarding of public morals (or rather, that the absence of measures would have a detrimental effect upon them). ${ }^{180}$ This approach stands in stark contrast to our current analysis of the cultural protection role of GIs, which demonstrates that some so-called cultural policies have no real effect on the protection of culture. Under current jurisprudence, evidence on the real futility of cultural protection through trade-restrictive exceptions might be ignored by WTO judicial bodies if adjudicated. This would be particularly problematic if, under the indispensability test, unworthy traderestrictive cultural policies were sustained under an Article XX of GATT-style or GATT-stylized cultural exception because there was no readily apparent less trade-restrictive policy alternative. This would be so even though the measures themselves were not in fact effective as cultural protectors.

Furthermore, this also becomes a burden of proof issue. While it is accepted that the party invoking an Article $X X$ of GATT/Article XIV of GATS exception (normally the respondent) bears the burden of proving the affirmative of the particular defense, ${ }^{181}$ in practice, it is the complainant who must show that

179 Id. at 16.494 .

180 This is even despite evidence provided by Antigua and Barbuda, the complainant in the case, whereby some U.S. military research had found that "the presence of military casinos did not have a negative effect on the morale or financial stability of the United States forces, their family members and other persons -including foreign nationals - who gambled at the government-owned facilities." US - Gambling I, supra note 162, at \ 6.480 .

181 See Appellate Body Report, United States-Measure Affecting Imports of https://scholarship.law.upenn.edu/jil/vol26/iss4/2 
the challenged measure is not indispensable in terms of the necessity test by demonstrating the existence of WTO-compliant or less inconsistent alternatives. If, as in US - Gambling among others, the respondent is not seriously required to show that the challenged measure has a materially positive effect on culture, the burden of proof is thus effectively shifted to the complainant (while the respondent must then rebut by showing that these alternatives are not "reasonably available"),182 and the substantive question of the absolute effectiveness of the challenged measures is bypassed. This grants both substantive and tactical advantages to the cultural consideration which, as our analysis of GIs demonstrates, may have no real empirical basis.

It is therefore evident that if "trade and culture" is to be taken seriously, the WTO dispute-settlement system should be more inquisitive regarding theories of non-trade cultural protection that are claimed to underlie trade restrictions. It should also devote more objective attention to the substantive question of whether challenged trade-restrictive measures do in fact contribute to the achievement of the protected non-trade value, such as culture and cultural diversity. This should occur well before consideration of the extent (interpreted as indispensability) of such protection. For example, if GIs had not (counterfactually) been established under specialized TRIPS rules, an investigation into the actual cultural effect of GIs might demonstrate their questionable contribution to cultural protection as presented in this Article, making unnecessary an examination of the theoretical degree of protection offered, both absolutely and in relation to conceivable alternatives.

\subsection{Thinking About a Parallel UNESCO Regime}

Circumventing the question of a cultural exception in WTO

Woven Wool Shirts and Blouses from India, WT/DS33/AB/R (Apr. 25 1997) ("It is only reasonable that the burden of establishing such a defence should rest on the party asserting it.")

182 The intricacy of the burdens of proof in Article XX, with special regard to the burden of proving the existence or absence of reasonably available alternatives is discussed by the Appellate Body in US - Gambling II, supra note 2, at 1 \ 309310. In its quest for certainty and clarity in the allocation of the burden of proof, the Appellate Body has explained its standards in this case, while in others it has merely compounded confusion, but discussion of this is for another article. Here I merely wish to point out that the tactical advantage granted to the party responding on the basis of a cultural exception by way of the "necessity" test has been construed in practice in combination with the burden of proof. 
law, the UNESCO Second Draft Convention, 183 upon entering into force in the future, may establish in more ways than one, a parallel or separate legal regime for the regulation of trade and culture with significant external impacts on the WTO. Under article 5(1) of the Second Draft Convention, states Parties will affirm "their sovereign right to adopt measures to protect and promote the diversity of cultural expressions within their territory." 184 "Cultural expressions" are broadly defined in article 4 of the Draft Convention as including the "cultural contents" of "cultural goods and services," 185 whose definition has already been discussed. ${ }^{186}$

Most importantly, under article 6(1) of the Second Draft Convention, "each [state] Party may adopt measures aimed at protecting and promoting the diversity of cultural expressions within its territory."187 Under article 6(2) of the Second Draft Convention, such protective and/or promotive cultural measures may include (among others) the following:

(a) regulatory measures aimed at protecting and promoting diversity of cultural expressions;

(b) measures that, in an appropriate manner, provide opportunities for domestic cultural activities, goods and services among all those available within the national territory for their creation, production, dissemination, distribution and enjoyment of such domestic cultural activities, goods and services, including provisions relating to the language used for such activities, goods and services;

(c) measures aimed at providing domestic independent cultural industries and activities in the informal sector effective access to the means of production, dissemination and distribution of cultural activities, goods and services;

(d) measures aimed at providing public financial assistance;

183 See supra note 5 (the analysis is subject to the caveat related to the adoption of the Convention, in the last sentence of the footnote).

184 UNESCO Second Draft Convention, supra note 4, art. 5(1).

185 Id. art. 4.

186 See supra text accompanying note 47.

187 UNESCO Second Draft Convention, supra note 4, art. 6(1). 
(e) measures aimed at encouraging non-profit organizations, as well as public and private institutions and artists and other cultural professionals, to develop and promote the free exchange and circulation of ideas, cultural expressions and cultural activities, goods and services, and to stimulate both the creative and entrepreneurial spirit in their activities;

(f) measures aimed at establishing and supporting public institutions, as appropriate;

(g) measures aimed at nurturing and supporting artists and others involved in the creation of cultural expressions;

(h) measures aimed at enhancing diversity of the media including through public service broadcasting. ${ }^{188}$

The only precondition required is that these measures be "within the framework of [the State Party's] cultural policies," which are broadly defined in article 4(6) of the Second Draft Convention as "policies and measures related to culture, whether at the local, national, regional or international level that are either focused on culture as such or are designed to have a direct effect on cultural expressions of individuals, groups or societies, including on the creation, production, dissemination, distribution of and access to cultural activities, goods and services." 189

In other words, it seems (without undertaking more detailed analysis) the UNESCO Draft Convention grants a virtual carte blanche to national discrimination in all relevant aspects of commercial activity (note the continued emphasis on "domestic" protection). That may take the form of WTO-inconsistent quantitative restrictions and measures of equivalent effect, or the provision of actionable or prohibited direct subsidies ("public financial assistance"), or other measures, as long as these national measures can fit into a framework of "cultural policies"; and these only need be "designed to have an effect" on cultural expressions. In terms of the trade and culture debate, this approach at least seems to grant full priority to a broadly defined vision of culture over all aspects of trade (however, the UNESCO Draft Convention

189 Id. art. 4(6). 
itself includes provisions that would promote access to international cultural expressions, somewhat balancing this initial assessment).

Of course one must ask what the status would be of these proposed UNESCO obligations and rights in the WTO in case of conflict of norms. Article 19 of the First Draft Convention provided for two possibilities. Under Option B, the Draft Convention would not "affect the rights and obligations of the States Parties under any other existing international instruments," 190 viz., when push came to shove, trade and culture issues would continue to be regulated by WTO disciplines not only in the WTO but in the entire fabric of legal relations between parties. Under the alternative Option A, however, a cultural priority was constructed. While the First Draft Convention's provisions would not affect international "intellectual property rights," existing international rights and obligations would step aside where they would "cause serious damage or threat to the diversity of cultural expressions." 191

The relationship between the proposed UNESCO Convention and other international obligations was the focus of heated debates during 2005, and can be expected to remain so. In the UNESCO Second Draft Convention of August 2005, article 20 emphasized that the Convention is not subordinate to any other treaty and attempts to establish inter-treaty normative comity, but then provides that "[n]othing in this Convention shall be interpreted as modifying rights and obligations of the Parties under any other treaties to which they are parties." 192

This legal construction does not seem satisfactorily meaningful for several reasons, but for present purposes suffice it to say that it does not allocate any weight to the question of whether the "cultural policies" at hand actually have any proven positive effect on cultural protection and diversity. This may lead to a significant

190 UNESCO First Draft Convention, supra note 4, art. 19, option B.

191 Id. art. 19.2, option A. For a more comprehensive blackletter analysis of the potential conflict of norms between the now superseded UNESCO First Draft Convention and WTO Agreements, from a general public international law perspective, see Jan Wouters \& Bart De Meester, UNESCO's Convention on Cultural Diversity and WTO Law: Complementary or Contradictory? (K.U. Leuven Faculty of Law Inst. for Int'l Law, Working Paper No. 73, Apr. 2005), available at http://www.law.kuleuven.be/iir/nl/wp/WP/WP73e.pdf (last visited Nov. 16, 2005).

192 UNESCO Second Draft Convention, supra, note 4, art. 20. 
expansion of the breadth of national policies that benefit from the Draft Convention's provisions without actually making a contribution to the achievement of the Draft Convention's purposes. Thus, while the idea of a separate UNESCO cultural protection regime is certainly a worthy one, in light of this Article's conclusions regarding the dubious merits of GIs as a form cultural policy, and the potentially material adverse effect of such a regime upon trade, it appears incumbent upon such a separate cultural regime to undertake a regulatory system that would more strictly define the cultural effects it intends to achieve, and more seriously monitor and verify the achievement of these effects.

As in our discussion of sui generis cultural protection and of a general cultural exception in WTO law, the actual positive influence of a proposed measure, whether international or national, upon cultural protection and diversity simply cannot be taken for granted. This is so even in the face of a persuasive cultural theory and within the framework of a parallel UNESCO regime of trade and culture.

\section{Digestivo: Of Cultural PRotection AND Cultural}

\section{PROTECTIONISM}

The challenge of the "Trade and Culture" nexus lies, like in other "Trade and _-." situations, in designing workable legal mechanisms for distinguishing between genuinely cultural national regulatory measures on the one hand, and measures whose effect is merely to distort international trade on the other; between cultural protection and cultural protectionism. In this article I have endeavored to demonstrate that GIs, as sui generis internationally-agreed-upon legal measures, are closer to the latter than the former. Furthermore, I have argued that in drawing the boundary between cultural protection and protectionism, "trade and culture" should be taken seriously, or rather, that culture itself should be taken seriously as a non-trade consideration. As the battle cry of the disgruntled Languedoc vigneron in this article's epigraph illustrates, the flag of culture is all too easily unfurled on behalf of trade protectionism. If, however, culture is to be taken seriously as a justification for trade-restrictive policies, it must first be proven that these policies do indeed contribute to the protection and promotion of local culture and to the safeguarding of cultural diversity. This must be the first test of a cultural policy; only then may it be allowed to establish digressions from general 
international trade law disciplines, through specialized mechanisms, under the rules of a general GATT/GATS cultural exception or through a separate UNESCO cultural diversity regime. This may seem to be a "trade first" approach, but it is no less a "culture first" one, because it would not tolerate the institution of rules of international cultural diversity law that may look good on paper but have no real effects on culture in practice.

A problem that perhaps distinguishes the "trade and culture" issue from other "trade and _- "relationships lies at the core. Are trade and culture really conflicting values with opposing interests? Both trade and culture are expressions of human activity and exchange; the exchange not only of goods and services, but also of ideas. As article 7 of the UNESCO Declaration acknowledges, "[c]reation draws on the roots of cultural tradition, but flourishes in contact with other cultures." 193 Culture is not static; it flows and changes as do the individuals who create and practice it. The traditions of today are the unthinkable innovations and foreign influences of yesteryear. Without international trade and interaction, global culture might simply dry up. The UNESCO Second Draft Convention appreciates this reality in a few of its provisions, but operatively does not accord it much space. ${ }^{194}$ As pressure mounts to establish international legal mechanisms of cultural protection that entail restrictions to trade, we must ask ourselves whether by curtailing economic human exchanges such mechanisms do not at the same time prevent human cultural exchanges in whose vibrancy lies the future of human cultural development and its diversity.

But these are thoughts best left for another meal. ${ }^{195}$

193 UNESCO Declaration, supra note 4, art. 7.

194 For definition of the concept of "interculturality," see Second Draft Convention, supra note 4 , art. 4.8 .

195 Readers with an interest in exploring these final questions more fully must read Tyler CoWEN, CReative Destruction: How Globalization is Changing the WORLD'S CULTURES (2002). 